Prepared in cooperation with the Washington State Department of Natural Resources and the City of Olympia

\title{
Effect of Simulated Tree Canopy Removal on a Municipal Wellfield in the Puget Sound Aquifer System, Thurston County, Washington
}

Open-File Report 2013-1291 



\section{Effect of Simulated Tree Canopy Removal on a Municipal Wellfield in the Puget Sound Aquifer System, Thurston County, Washington}

By Kenneth H. Johnson

Prepared in cooperation with the Washington State Department of Natural Resources and the City of Olympia

Open-File Report 2013-1291 


\section{U.S. Department of the Interior \\ SALLY JEWELL, Secretary}

\section{U.S. Geological Survey \\ Suzette M. Kimball, Acting Director}

U.S. Geological Survey, Reston, Virginia: 2014

For more information on the USGS-the Federal source for science about the Earth, its natural and living resources, natural hazards, and the environment-visit http://www.usgs.gov or call 1-888-ASK-USGS

For an overview of USGS information products, including maps, imagery, and publications, visit $h$ ttp://www.usgs.gov/pubprod

To order this and other USGS information products, visit http://store.usgs.gov

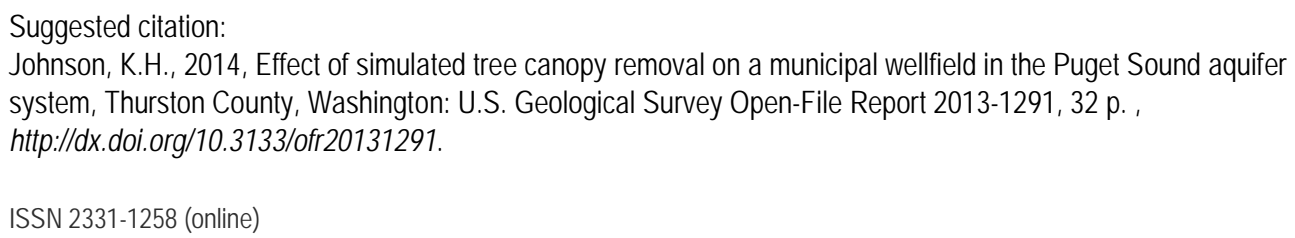

Any use of trade, firm, or product names is for descriptive purposes only and does not imply endorsement by the U.S. Government.

Although this information product, for the most part, is in the public domain, it also may contain copyrighted materials as noted in the text. Permission to reproduce copyrighted items must be secured from the copyright owner. 


\section{Contents}

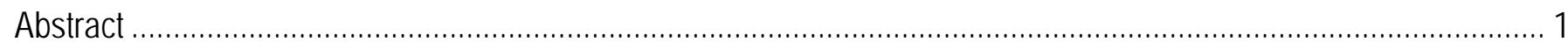

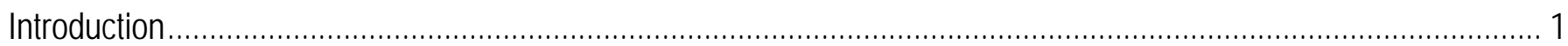

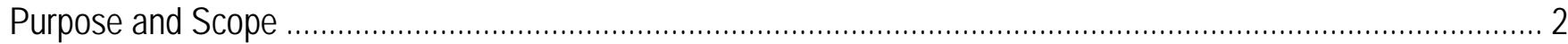

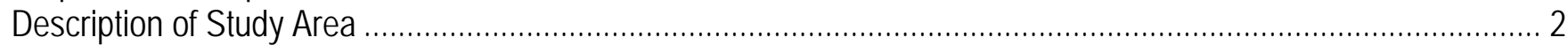

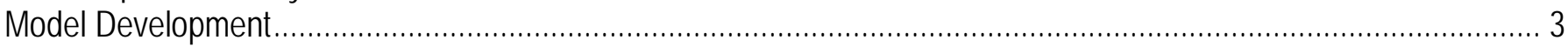

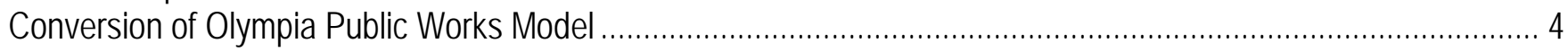

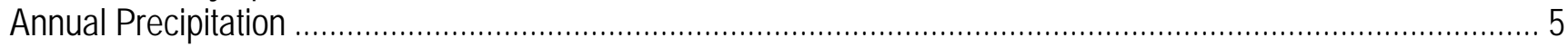

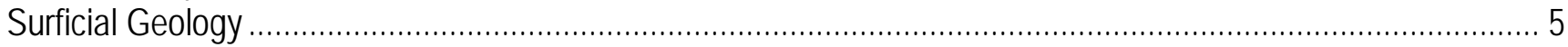

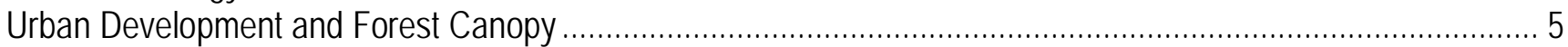

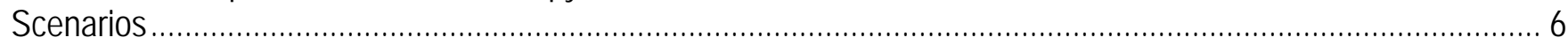

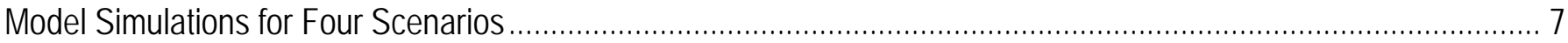

Scenario 1-Base Case: Present-Day (2006) Tree Canopy Cover................................................................... 7

Scenario 2-All Tree Canopy Removed Throughout Model Extent ………….................................................... 8

Scenario 3-Tree Canopy Removed from All Privately Owned Parcels in Wellhead Protection Area ...................... 8

Scenario 4-Tree Canopy Removed from Only Two Parcels (36440004100 and 21832340000) …..................... 9

Concerns Common to All Scenarios .......................................................................................... 9

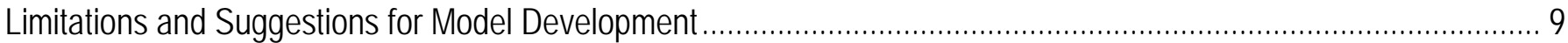

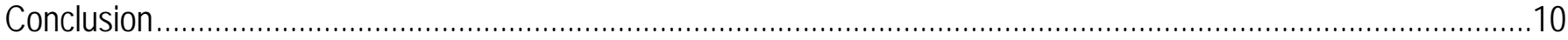

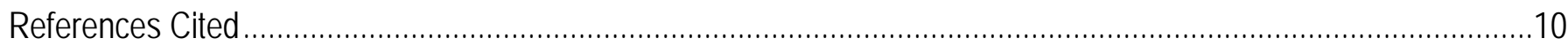

\section{Figures}

Figure 1. Map showing general vicinity of Olympia Public Works (2002) model extent and location of new

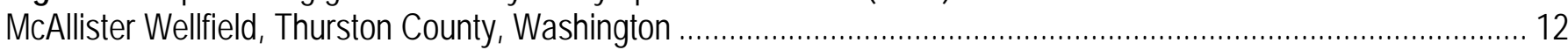

Figure 2. Map showing extent of active model by Drost and others (1999), compared to model developed for Olympia Public Works (2002), Thurston County, Washington ........................................................................... 13

Figure 3. Map showing surficial geologic units (Washington State Department of Natural Resources, Geology and Earth Resources Division 2010), Thurston County, Washington...................................................... 14

Figure 4. Map showing recharge category and developed land cover, Thurston County, Washington....................... 15

Figure 5. Map showing present-day (2006) Base Case (Scenario 1) tree canopy percentages,

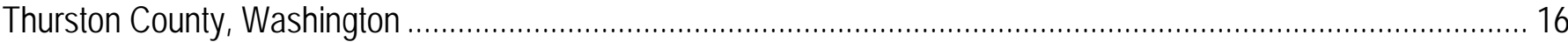

Figure 6. Graph showing precipitation / recharge relations used in this study (after Bidlake and Payne, 2001) for different recharge categories and varying canopy percentages on aquifer materials ............................................. 17

Figure 7. Map showing distribution of average annual groundwater recharge from normal precipitation for present-day (2006) Base Case (Scenario 1) tree canopy cover conditions, Thurston County, Washington ............... 18 Figure 8. Map showing simulated groundwater levels averaged for model layers 7 and 8, for present-day (2006) Base Case (Scenario 1) recharge...................................................................................................... 19

Figure 9. Map showing local simulated water levels, particle tracking, and capture zones for present-day (2006) recharge, Base Case (Scenario 1), Thurston County, Washington .................................................................... 20 Figure 10. Previously mapped Wellhead Protection Area (Olympia Public Works, 2008) and parcels for modification in Scenarios 3 and 4 .....

Figure 11. Map showing simulated change in recharge between Base Case (Scenario 1) and Scenario 2 (All Tree Canopy Removed), Thurston County, Washington.

Figure 12. Map showing simulated groundwater-level change (ft) between the Base Case (Scenario 1) and Scenario 2 (all Tree Canopy removed throughout model area), averaged for model layers 7 and 8, and particle tracks and capture zones for Scenario 2, Thurston County, Washington. 
Figure 13. Map showing change of recharge for Scenario 3 (tree canopy removed from all local private parcels) compared to Base Case (Scenario 1) and previously mapped Wellhead Protection Areas (Olympia Public Works, 2008), Thurston County, Washington

Figure 14. Change of simulated groundwater-level rise (in feet) compared to Base Case (Scenario 1), and particle tracks and capture zones for Scenario 3 (tree canopy removed from all local private parcels), Thurston County, Washington.

Figure 15. Map showing change of recharge for Scenario 4 (tree canopy removed from two parcels) compared to Base Case (Scenario 1) and previously mapped Wellhead Protection Areas (Olympia Public Works, 2008) 26

Figure 16. Map showing change in simulated groundwater level rise (ft), averaged for model layers 7 and 8 , for Scenario 4 compared to Base Case (Scenario 1), and particle tracks and capture zones for Scenario 4 (Tree canopy removed from two parcels), Thurston County, Washington.

\section{Tables}

Table 1. Precipitation and recharge relationships used in this study..... 28

Table 2. Descriptions of hydrogeologic units and assigned model layers

Table 3. Scale 1:100,000 Geologic Units from Washington State Department of Natural Resources, Geology and Earth Resources Division (2010) and assigned recharge categories 30

Table 4. Tree canopy changes for recharge inputs in four scenarios ................................................................. 30

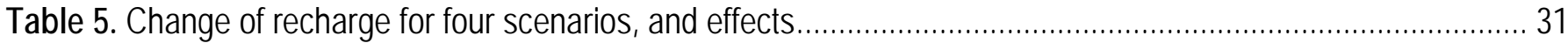

Table 6. Change in area of Capture Zone for four scenarios 


\section{Conversion Factors and Datums}

\section{Conversion Factors}

Inch/Pound to SI

\begin{tabular}{|c|c|c|}
\hline Multiply & By & To obtain \\
\hline \multicolumn{3}{|c|}{ Length } \\
\hline inch (in.) & 2.54 & centimeter $(\mathrm{cm})$ \\
\hline inch (in.) & 25.4 & millimeter (mm) \\
\hline foot (ft) & 0.3048 & meter (m) \\
\hline mile (mi) & 1.609 & kilometer (km) \\
\hline \multicolumn{3}{|c|}{ Area } \\
\hline square mile $\left(\mathrm{mi}^{2}\right)$ & 259.0 & hectare (ha) \\
\hline square mile $\left(\mathrm{mi}^{2}\right)$ & 2.590 & square kilometer $\left(\mathrm{km}^{2}\right)$ \\
\hline \multicolumn{3}{|c|}{ Volume } \\
\hline million gallons (Mgal) & 3,785 & cubic meter $\left(\mathrm{m}^{3}\right)$ \\
\hline acre-foot (acre-ft) & 1,233 & cubic meter $\left(\mathrm{m}^{3}\right)$ \\
\hline acre-foot (acre-ft) & 0.001233 & cubic hectometer $\left(\mathrm{hm}^{3}\right)$ \\
\hline \multicolumn{3}{|c|}{ Flow rate } \\
\hline acre-foot per year (acre-ft/yr) & 1,233 & cubic meter per year $\left(\mathrm{m}^{3} / \mathrm{yr}\right)$ \\
\hline acre-foot per year (acre-ft/yr) & 0.001233 & $\begin{array}{l}\text { cubic hectometer per year } \\
\left(\mathrm{hm}^{3} / \mathrm{yr}\right)\end{array}$ \\
\hline million gallons per day (Mgal/d) & 0.04381 & cubic meter per second $\left(\mathrm{m}^{3} / \mathrm{s}\right)$ \\
\hline inch per year (in/yr) & 25.4 & millimeter per year (mm/yr) \\
\hline
\end{tabular}

\section{Datums}

Vertical coordinate information is referenced to the North American Vertical Datum of 1988 (NAVD 88). Horizontal coordinate information is referenced to the North American Datum of 1983 (NAD 83).

Altitude, as used in this report, refers to distance above the vertical datum. 
This page left intentionally blank 


\title{
Effects of Simulated Tree Canopy Removal on a Municipal Wellfield in the Puget Sound Aquifer System, Thurston County, Washington
}

\author{
By Kenneth H. Johnson
}

\begin{abstract}
Effects of tree canopy removal on a wellfield were simulated using a groundwater flow model characteristic of hydrogeologic settings in the Puget Sound aquifer system. Effects were estimated according to simulated changes in flow patterns that may result from tree canopy removal associated with varying degrees of residential development. The flow model used was a modified version of a model of the hydrogeologic setting in Thurston County, Washington; the wellfield was one planned for Olympia, Washington, and the canopy modifications spanned a range of possible land use change scenarios. The relative effects of tree canopy removal were estimated in terms of potential changes in capture zones for the wellfield and groundwater levels. Because of the depth of the wellfield and the dispersal of the effects from changes in recharge at ground surface, potential changes in wellfield capture zones and groundwater levels were discernible but small compared to other possible influences.
\end{abstract}

\section{Introduction}

Groundwater suppliers in the Puget Sound lowlands have a need to quantify the linkages between forest management and the protection of groundwater quantity and quality. Variations in groundwater recharge caused by forest management activities, such as clear cutting, may change groundwater levels and flow paths that directly influence the size and shape of wellfield capture zones. Changes in the size and shape of wellfield capture zones could result in the inclusion of potential contaminant sources previously outside of the area contributing water to the wellfield, and changes in groundwater levels could reduce the quantity of water available for withdrawals.

The City of Olympia Public Works Department (Olympia Public Works) is actively pursuing the development of a new water source that will replace McAllister Springs as the primary supply of drinking water. The new water source, named the McAllister Wellfield, will be significantly more protected, more productive, and will meet water-supply needs into the future. Olympia Public Works has relied on McAllister Springs for more than 60 years to meet the city's water supply needs. Located at the headwaters of McAllister Creek, McAllister Springs provides high-quality water but is vulnerable to potential contamination, and will require extensive treatment if it is not retired within the next few years. The City began working on its plan to address this situation in the 1990s and, after extensive research, identified and purchased the McAllister Wellfield site, which is located about 1 mi southeast of the springs. Studies of the site showed that the wellfield overlies a large sustainable aquifer with high-quality water. With the purchase of the site, as well as 100 acres of adjacent development rights, the City has begun the long-term process of developing the wellfield as its primary source of drinking water. 
The U.S. Geological Survey previously constructed a three-dimensional numerical model of steady-state groundwater flow in the unconsolidated sediments of Thurston County, including the McAllister gravel aquifer which will supply water to the McAllister Wellfield. The USGS model is capable of delineating the recharge area of water-supply wells (Drost and others, 1999) in a hydrogeologic setting typical of the Puget Sound aquifer system. This model was subsequently modified by CDM Smith, Inc. and S.S. Papadopulos \& Associates, Inc. for use by Olympia Public Works (Olympia Public Works, 2002). The model was also used for delineation of capture zones (Wellhead Protection Area, or WHPA [Olympia Public Works, 2008]) for the McAllister Wellfield, and to support comprehensive planning for future development of water supplies for the municipalities in the area, including Olympia, Lacey, and Yelm (City of Olympia [2009], City of Lacey [2013], and City of Yelm [2011]). A test case that characterizes these comprehensive plans was used for modeling in this study.

\section{Purpose and Scope}

The objective of the study was to determine whether increased areal recharge accompanying tree canopy removal near the McAllister wellfield would affect groundwater flows and flowpaths induced by the wellfield. A somewhat generalized groundwater-flow model that was adapted from two previous models of the area was developed to simulate the potential effects under three scenarios of future tree canopy removal. This report includes descriptions of the hydrogeology of the area, model development, the scenarios that were devised to address concerns regarding tree canopy removal, and the results that were obtained with the modeling effort.

\section{Description of Study Area}

The groundwater-flow model used in this study covers an area of about $203 \mathrm{mi}^{2}$ in northeastern Thurston County, Washington (fig. 1). The hydrogeologic units and their characteristics incorporated into the model are typical of the alluvial, glacial, and interglacial Quaternary-age sediments that compose the Puget Sound aquifer system.

Several major hydrologic features were used as hydrologic boundaries of the groundwater-flow model. The model area is bounded to the northeast by the Nisqually River, to the west and southwest by the Deschutes River valley, and extends northward to Puget Sound and southeastward to an area where glacially derived water-bearing hydrogeologic units become thin and less productive.

The model area lies near the southern terminus of the most recent (Fraser) glaciation and is underlain by a northerly thickening sequence of unconsolidated glacial (till, outwash, and kame and kettle) and interglacial (alluvial and lacustrine) deposits. Sedimentary and volcanic bedrock units underlie the unconsolidated deposits and crop out in a few limited areas along the edges of the Deschutes River valley along the southwestern margin of the model area. The largest lakes in area are Long Lake, Pattison Lake, Lake St. Clair, and Hicks Lake. Major streams include Woodland, Spurgeon, Woodard, McAllister, and Yelm Creeks. 
The model area has a temperate marine climate with warm, dry summers, and cool, wet winters. Average annual precipitation (1981-2010) is 50.0 in. at Olympia Airport (National Oceanic and Atmospheric Administration, 2012). Land-surface altitude in the model area ranges from sea level along the Puget Sound coast to higher than $500 \mathrm{ft}$ in hills in the southern part of the model area.

The model area includes portions of five cities: Olympia, Lacey, Tumwater, Yelm, and Rainier (fig. 1). These cities obtain their public water primarily from groundwater (including springs sources). Olympia's main supply has been McAllister Springs, but the city is in the process of replacing the spring source with water from a wellfield about $1 \mathrm{mi}$ southeast of the springs. This study is part of an effort to protect the new wellfield from the effects of changes in land use, and specifically from the effects of tree removal as a result of residential development.

\section{Model Development}

The model that was used for this study was developed to explore potential effects of changing the recharge to groundwater that might be caused by tree canopy removal. The model was based on two previous groundwater flow models covering the study area. The previous models include one developed by consultants (CDM Smith and S.S. Papadopulos \& Associates, Inc.) for Olympia Public Works (2002); the second model was an earlier U.S. Geological Survey (USGS) model (Drost and others, 1999). For this study, the Olympia Public Works model was modified by converting it to steady state conditions and by changing the recharge boundary condition to include effects of land use (impervious surface) and tree canopy, and by updating precipitation and surficial geology (Bidlake and Payne, 2001) information. The model was run for a Base Case (Scenario 1) with present-day (2006) land cover, and again separately for three other scenarios with different extents of reduced tree canopy cover. The effects of the changes in recharge were demonstrated by simulated differences in head, changes to particle tracking toward the wellfield (using MODPATH, version 6 [Pollock, 2012]), and changes to various flow components.

It was beyond the scope of this study to calibrate the modified model with measured hydrologic data that are consistent in time with the updated land cover and precipitation data incorporated into the model, so the model is considered 'exploratory' in that the accuracy of the simulated groundwater levels and particle tracks is unknown. However, the hydrogeologic framework and properties of the modified model are representative of conditions in the study area, so measures of relative change in groundwater levels and particle tracks between scenarios are informative.

The previously constructed USGS model (Drost and others, 1999) was refined by CDM Smith, Inc. (Olympia Public Works, 2002) and S.S. Papadopulos \& Associates, Inc. (Olympia Public Works and Nisqually Tribe, 2010) for the Olympia Public Works Department, with a focus on the specific area around the McAllister Springs and the new McAllister Wellfield (fig. 2). During this revision of the model, the consultants used a non-standard (non-USGS) version of MODFLOW, called MODFLOWSURFACT (HydroGeoLogic, Inc., 1996), to avoid numerical instability due to wetting/drying of model cells (Olympia Public Works, 2002, p. 3-2).

The Olympia Public Works model was provided by Michael Riley and Stephen Thomas (Anchor QEA, Inc., written commun., January 30, 2013; and Shannon \& Wilson, Inc., written commun., February 19, 2013, respectively) in the form of input files for Groundwater Vistas (GW Vistas), a graphical user interface developed by Environmental Simulations, Inc. (2011), to connect with various versions of MODFLOW. The GWVistas file incorporated a test case for the Olympia Public Works model, called “Comp_20d”, that simulates full water rights applications for Olympia, Lacey, and Yelm-including Olympia Public Works’s switch from McAllister Springs to the new wellfield; a number of changes in well locations and flow rates for Lacey; and some new upland wells for Yelm, 
many of which are not in production, yet. Finally, the Comp_20d test case (the name refers to the Comprehensive Water System Plans for the three cities, for example, City of Olympia [2009], City of Yelm [2011], and City of Lacey [2013]) also includes features for the water rights mitigation plans for each city. The test case also was provided with output files to confirm that the model was successfully transferred to the USGS.

After receiving the Olympia Public Works model, the Comp_20d test case was simulated using MODFLOW-NWT (Niswonger and others, 2011), a standard MODFLOW version that provides similar rewetting and solver capabilities as were needed from MODFLOW-SURFACT. Although GW Vistas was able to produce essentially identical MODFLOW input files, including conversions from the Block Centered Flow package to the Layer Property Flow package and conversion to the Upstream Weighting package for standard MODFLOW, it was determined that the standard MODFLOW-NWT software did not reproduce sufficiently similar results for the Comp_20d test case. The MODFLOW-SURFACT simulates slightly lower heads (average about $4 \mathrm{ft}$ ), and a greater seasonal fluctuation of groundwater levels than MODFLOW-NWT. Additionally, the simulated flows at the boundaries differ. The differences are especially large for the distant upgradient (southeastern) boundaries of the Olympia Public Works model extent where constant head nodes along the boundary provide large flows to maintain the constant heads.

Because the Olympia Public Works model (using MODFLOW-SURFACT) and the Comp_20d test case had been developed for the Olympia Public Works and had been calibrated to field data, it was deemed important to use a base model that more closely replicated that model. The Comp_20d test case was simulated using a new version of MODFLOW-SURFACT and the results agreed closely with results from the original model. The two versions of MODFLOW-SURFACT used the same solver (conjugate gradient solution package PCG4, version 3, with N-R method flow solver), but used different versions of certain modules (BAS5 versus BAS1 for the MODFLOW Basic package and BCF4 versus BCF3 for the MODFLOW Block Centered Flow package), and had somewhat different formatting in the output listing. However, the reported component flows for each timestep differed by less than about 0.0015 percent of the total model flow-the largest differences were for flows from storage and from constant head nodes. The heads in the final time step for the two simulations were $\pm 0.003 \mathrm{ft}$ in all cells and all layers, which is less than 0.001 percent of the range of head values $(1.0-457.4 \mathrm{ft})$ across the entire model extent.

\section{Conversion of Olympia Public Works Model}

For the purposes of this study, the original Comp_20d test case for the Olympia Public Works model was (1) converted from a transient (6 years of monthly stress periods each with eight time steps) to steady-state (average annual) flow conditions, and (2) recharge was simulated using a new precipitation-recharge relation.

The recharge and well boundary conditions in the original Olympia Public Works model varied only seasonally. Other boundary conditions (for example, constant heads, drains, and rivers) did not vary. Thus, for the purposes of simulating groundwater transport at the depth of the wellfield, steadystate conditions at average annual levels were deemed adequate to represent the system.

For the purposes of this study, steady-state well boundary conditions were imposed using annual average withdrawals for all wells, because the original Comp_20d test case represented the system under "full water rights applications" and “mitigation plans" for the major water systems (Olympia, Lacey, and Yelm) (M.J. Riley, Anchor QEA, Inc, written commun., February 11, 2013). Other model boundary conditions that were time invariant were unchanged from the original Olympia Public Works model. 
The original Olympia Public Works model based its recharge on the Drost and others (1999) model, and did not consider the effects of tree canopy. For this study, the recharge estimate was modified to use the method developed by Bidlake and Payne (2001) for general Puget Sound conditions. The new recharge boundary condition was based on:

- Annual precipitation

- Surficial geology

- Urban development cover (areas of concentrated impervious surface)

- Forest canopy cover

\section{Annual Precipitation}

Annual precipitation was input as "Normal” precipitation (30-year average from 1981 to 2010, according to National Oceanic and Atmospheric Administration [2012] definition) distributed spatially throughout the model extent according to the Geographic Information Systems (GIS) coverage developed by the Natural Resources Conservation Service / PRISM Climate Group (2013). The earlier models (Drost and others, 1999; Olympia Public Works, 2002) had used a precipitation distribution based on isopleths from a National Weather Service mapping from 1965 (U.S. Weather Bureau, 1965), and converted precipitation to recharge using different relationships (Drost and others, 1999).

For the present study, recharge was computed from precipitation for each model cell according to linear regressions developed for Puget Sound conditions (Bidlake and Payne, 2001). Four different regression equations were used (table 1 ).

\section{Surficial Geology}

Surficial geology was obtained from mapped coverages at a scale of 1:100,000 from Washington State Department of Natural Resources, Geology and Earth Resources Division (2010), figure 3 shows the geologic units present at land surface in the area. Geologic units were grouped into hydrogeologic units consisting of aquifers, confining units, and bedrock, based on similarities in lithology, hydrologic characteristics, and relative stratigraphic position. Table 2 provides descriptions of regional hydrogeologic units, both at the ground surface and at depth, and the associated model layers and categories (aquifer vs confining unit / till) that were generally followed by both the Drost and others (1999) model as well as in the Olympia Public Works (2002) model. The model used in the present study kept the same layering and aquifer properties from the Olympia Public Works model while assigning appropriate recharge categories (aquifer, confining unit, or bedrock as in Table 1) to the surficial expressions of each hydrogeologic unit (table 3) as spatially distributed throughout the area (fig. 4).

\section{Urban Development and Forest Canopy}

Urban development and forest canopy land cover information was obtained from the Washington State Department of Ecology (2013) Western Washington Land Cover Change project (data are current as of 2006). For developed urban areas, the following land cover values were used, as shown in figure 4: High Intensity Developed; Medium Intensity Developed; and Low Intensity Developed. Model cells with these values were assigned the same recharge relationship as bedrock geologic units. Although there actually may be different recharge rates among these three different development intensity zones, only one recharge relationship was used, in accordance with the procedure used by Bidlake and Payne (2001). 
In aquifer areas, recharge was modified according to the areal portion of each cell that contained “forested" land cover. Tree canopy in each model cell (0-100 percent) was calculated from the raster canopy data from the Washington State Department of Ecology (2013) using Geographical Information Systems (GIS) methods (fig. 5). The recharge for the cell was accordingly interpolated between the forested and the unforested regression values (fig. 6). Interpolating between different quantities of canopy also allowed the effects of small changes in tree canopy on recharge to be simulated. Figure 6 also shows the calculation of recharge for all other recharge categories including the precipitation and recharge relationships for areas underlain by confining units and bedrock (or urban developed) and zero recharge for areas occupied by surface-water bodies, because interflows between surface water and groundwater are simulated by other boundary conditions.

Other "special” recharge relationships used in the original Olympia Public Works model and simulated in the present study as average annual rates include:

- Areas around the edge of Lake St. Clair: recharge = 262.98 inches/year.

- Artificial recharge facility near McKenzie Lake in Yelm (mitigation feature): recharge = 135.07 inches/year.

The model as adapted for the present study was used to simulate four scenarios (table 4) of different quantities of recharge applied to the model. The areal distribution of average annual recharge from normal precipitation (1981-2010) for 2006 land cover conditions (fig. 7) used in Scenario 1 (table 4) for this study was calculated to be 213,271 acre-ft/yr (table 5) using land cover, as previously discussed, and normal precipitation (Natural Resources Conservation Service/PRISM Climate Group, 2013; as described in section, “Annual Precipitation”) for the entire model area. This value represents a 14 percent decrease from average annual recharge previously used in the original Olympia Public Works model (248,389 acre-ft/yr). This difference is due to the use of different precipitation (and surficial geology) data as well as revised precipitation/recharge relationships, although the contributing effects of these two factors could not be separated and individually quantified.

\section{Scenarios}

The original Olympia Public Works model, modified to simulate steady-state conditions as described in section, "Conversion of Olympia Public Works Model," was used to simulate the effects of four scenarios representing a range of potential groundwater-recharge conditions (table 4).

All four scenarios used the same well withdrawals, as well as the heads and other parameters for all lakes, streams, and other boundary conditions. Scenario 1 was simulates present day recharge but with full water rights applications and mitigations for Olympia, Lacey, and Yelm. Scenario 2 simulates the effects or tree canopy removal throughout the model extent, and represents an extreme condition that provides an upper limit to simulations, and is not considered realistic.

Scenarios 3 and 4 use the parcel database for Thurston County GeoData Center (2013) provided by Washington State Department of Natural Resources (DNR) to allow selection of appropriate parcels for changes in tree canopy. Personnel at the Olympia Public Works (Donna Buxton, written commun., June 4, 2013) provided the details for the preferred scenarios and, in particular, the two parcels that were of greatest interest as locations for preserving tree canopy.

Changes in recharge were applied by increasing recharge in selected cells containing tree canopy cover in areas underlain by aquifer units, and ranging from the present day value to the recharge value for zero tree canopy. A model cell was considered in a parcel when its centroid lay within the polygon of the parcel. Some anomalous recharge values were adjusted to avoid gaps where the centroid happened to fall in a right-of-way. 


\section{Model Simulations for Four Scenarios}

The four scenarios were set up in GW Vistas (Environmental Simulations, Inc., 2011), compiled into input files for MODFLOW-SURFACT (HydroGeoLogic, Inc., 1996), executed, and then the scenario results were post-processed and analyzed in GW Vistas and Arc Map (Environmental Systems Research Institute, 2010). Particle tracking was accomplished with MODPATH (Pollock, 2012), also within the GW Vistas interface. The results from the four scenario simulations can be compared by changes in flows, changes in groundwater levels, or changes in particle trajectory. The results also can be compared at different scales throughout the model extent or locally in the vicinity of the McAllister Wellfield. Because of the concern about the wellfield and its capture zone, much of the following discussion focuses on the immediate vicinity of the wellfield and the screen zone depths of the wells in the wellfield.

The McAllister Wellfield includes six wells: PW-24, -25, -26, -27, -28, and TW-22, that are simulated for this study as they were in the original Olympia Public Works model, Comp_20d test case, to withdraw a total of 17,800 acre-ft/yr (15.9 Mgal/d) from model layers 7 and 8 . Although the wellfield represents approximately 41 percent of the total simulated well withdrawals in the model area, these withdrawals represent only about 7-8 percent of the total estimated recharge to the model area. These wells are screened in layers 7 and 8 of the model, a characterization carried over from the Olympia Public Works (2002) model. In other portions of the model these layers represent older undifferentiated geologic units, TQu (table 2 model layers 6 and 7 in Drost and others [1999]) but in the vicinity of the wellfield, these layers are part of the highly conductive McAllister Gravel unit (in layers 2 through 8 of the present model, based on the Olympia Public Works [2002] model, see table 2). The layers that are screened by these wells extend from about -50 to about -290 ft NAVD, or to depths of about 200-450 ft.

\section{Scenario 1-Base Case: Present-Day (2006) Tree Canopy Cover}

Simulated composite groundwater levels (averaged values for model layers 7 and 8) for Scenario 1 (fig. 8) indicate that flow is to the northwest in the southern part of the area and to the north in the northern part of the area, and ranges from about $450 \mathrm{ft}$ altitude in the foothills of the Cascade Mountains in the south to nearly sea level as groundwater discharges to Puget Sound in the north. In the vicinity of the wellfield, there is a localized depression in simulated groundwater levels suggesting convergent flow resulting from simulated withdrawals at the wellfield and the highly conductive zones in the area. This convergent flow pattern is better delineated in the more detailed groundwater levels shown in figure 9.

The particle transport paths are also shown in figure 9. The particles are started from 24 evenly spaced points along a circle with a radius of 1,000 ft from the pumping centroid of the wellfield, and at two depths (at the mid-depths of model layers 7 and 8). The particles are traced backwards (upgradient) along simulated groundwater-flow paths and the time of travel (TOT) is reported for each particle to move from a plotted end point to the starting point along the circle. The particle locations are shown in different colors for TOTs of 6 months, and 1, 5, and 10 years (fig. 9). A polygon for each TOT for the capture zones of the wellfield was derived that encompasses all particle traces less than the specified TOT. 
Olympia Public Works (Donna Buxton, written commun., April 26, 2013) provided a shape file (fig. 10), of the capture zones (Wellhead Protection Areas or WHPA) for the McAllister Wellfield (Olympia Public Works, 2008), which was developed with the Olympia Public Works model (Olympia Public Works, 2002), but with slightly different well withdrawals and mitigation features. This previously delineated Wellhead Protection Areas (fig. 10) was slightly different (generally larger) than the capture zones derived for Scenario 1 (fig. 9). This is attributed to differences in recharge, locations or the number of the particle starting points, locations and quantities of the pumping, or inclusion of dispersion in the calculation; or because transient groundwater flow was simulated in the WHPA case, whereas steady-state flow was simulated in this study. Regardless, it is not known which simulated capture zone is more accurate, and for the purposes of this study, it was sufficient to compare results of subsequent scenarios to the newly calculated capture zones for Scenario 1 (fig. 9).

\section{Scenario 2-All Tree Canopy Removed Throughout Model Extent}

Scenario 2 was devised as an extreme condition (table 4), and recharge for all the surficial "glacial outwash and other alluvium" cells throughout the model area was computed using the "nonforest aquifer" recharge equation, as defined in table 1. Recharge in till areas, bedrock, urban development, special recharge areas, and open water were the same as in Scenario 1. The change of recharge is shown in figure 11 and table 5, and the resulting changes of simulated composite groundwater levels (averaged values for model layers 7 and 8 to represent the aquifer in which the wellfield wells are screened), in the vicinity of the capture zone, are shown in figure 12. As listed in table 5, recharge for Scenario 2 increased by almost 10 percent throughout the model area compared to the recharge for Scenario 1.

The increase in simulated recharge did not have a large effect (1-6 percent increase in area) on the size of the capture zones (table 6 and fig. 12) because: (1) simulated wellfield withdrawals occur deep in the aquifer system (model layers 7 and 8) where the effects of changes in recharge are dispersed and attenuated, and (2) most of the increase in simulated recharge, between Scenario 1 and 2, exits the aquifer system as groundwater discharge (table 5) at model boundaries (constant head nodes, rivers and drains). Increased outflow to these boundaries, located peripherally to the wellfield, causes increased groundwater flow in those directions, and broadens the capture zone.

\section{Scenario 3-Tree Canopy Removed from All Privately Owned Parcels in Wellhead Protection Area}

Scenario 3 involved removing tree canopy (cutting all trees) from all private parcels in the vicinity of the previously mapped WHPA (shown in fig. 10). The parcels were selected on the basis that they overlapped the WHPA polygons provided by the City of Olympia, IT GIS Team (Olympia Public Works, 2008). Publicly-owned parcels were dropped from the tree canopy changes based on the name of the property owner, including U.S. Army, Washington DNR, City of Olympia, Nisqually Indian Tribe, Thurston County, and Washington State Game Department. There remained some 900 privately owned parcels that were affected by the scenario. These parcels, private and public, are indicated in figure 10. The distribution of the increase in recharge is shown in figure 13, and the resulting particle paths and changes of groundwater levels (in layers 7 and 8, averaged) are shown in figure 14.

The change in recharge was much less in Scenario 3 than Scenario 2, because tree canopy in only the parcels in the local area were removed, rather than throughout the model extent. The change of recharge was only about 0.26 percent (table 5). The increased recharge was found to exit the system mostly by drains just to the east of the wellfield, because of their proximity, with a lesser amount to constant head nodes and rivers farther away. The area of the capture zone is only slightly changed from Scenario 1, and the largest zone $(<10$-year TOT) decreased in area. 


\section{Scenario 4-Tree Canopy Removed from Only Two Parcels (36440004100 and 21832340000)}

Scenario 4 reduced the affected tree canopy removal areas in Scenario 3 to only two parcels (figure 10). These two parcels were selected by Olympia Public Works as prime candidates for possible purchase and preservation. The change of recharge is shown in figure 15, and the changes of groundwater level and the resulting particle tracks are shown in figure 16. The removal of tree canopy in these two parcels increases total recharge in the model by only 0.03 percent compared with Scenario 1 (table 5).

\section{Concerns Common to All Scenarios}

It is possible that the slight movement of the model-derived capture zone between the different scenarios could result in a potential source of contamination to be moved into (or out of) the capture zone. It should also be noted that the capture zones are based on travel in the aquifer, and not from the ground surface. Travel times from sources at ground surface would be longer (greater than 10 years) and possibly different in extent.

Though water quality implications are beyond the scope of this study, there may be some concerns that nitrate can increase in groundwater when vegetative cover is removed. While this is a possible outcome, the potential impact is greatly reduced by the depth of the wells in the wellfield.

\section{Limitations and Suggestions for Model Development}

The Olympia Public Works model was modified for this study and but not recalibrated with either existing or new data. Thus, the modified model used for this study should be considered a conceptual model of aquifer systems typical of the Puget Sound lowlands rather than an updated model of the actual aquifer system in Thurston County.

It would be beneficial to inventory actual groundwater use in the area to produce updated withdrawal data, and then recalibrate using updated groundwater-level and stream discharge measurements. The proprietary software package used for the Olympia Public Works model and the model used in this study, MODFLOW-SURFACT, limits the ability of others to apply this model. However, if the model were to be redeveloped with updated data and recalibrated, a standard nonproprietary software package would make the model more available to others. Newer open-source software (MODFLOW-NWT; Niswonger and others, 2011) could be used, and the model recalibrated with more powerful parameter-estimation methodologies (such as PEST; Watermark Numerical Computing, 2010). Such an enhanced model should be extended over a larger extent, such as across the entire Nisqually River basin, and allowed to connect with the Chambers-Clover Creek model to the northeast, as was developed by Johnson and others (2011). 


\section{Conclusion}

Changes in tree canopy can be simulated to estimate changes in recharge, and groundwater flow and capture zone extents. Simulated changes in the extent of tree canopy in the model area changes recharge only slightly and occurs in limited areas, so the effects, on groundwater availability are limited in magnitude. The small changes in recharge become greatly dispersed and attenuated at the depths of 300 feet or greater, typical of municipal wellfields in the Puget Sound aquifer system. The resulting changes to particle tracks and overall capture zones that were calculated for the scenarios simulated for the new McAllister Wellfield were minimal in extent and detail.

\section{References Cited}

Bidlake, W.R., and Payne, K.L., 2001, Estimating recharge to ground water from precipitation at Naval Submarine Base Bangor and vicinity, Kitsap County, Washington: U.S. Geological Survey WaterResources Investigations Report 01-4110, 33 p.

City of Lacey, 2013, Water system comprehensive plan update: Lacey, Wash., City of Lacey, Prepared under the direction of Lara Kammerect, P.E., Carollo Engineers, and Peter C. Brooks, P.E., accessed November 5, 2013, at http://www.ci.lacey.wa.us/city-government/city-departments/publicworks/plans-and-documents/library/comprehensive-water-plan.

City of Olympia, Public Works Department, 2002, McAllister Wellfield numerical model (Interim Report): Prepared by CDM Smith, Inc., for the City of Olympia Public Works Department, accessed November 5, 2013, at http://olympiawa.gov/ /media/Files/PublicWorks/Water-Resources/McAllisterWellfield-Model-Sec1-to-4-Figures-Interim.ashx, and http://olympiawa.gov/ /media/Files/PublicWorks/Water-Resources/McAllister-Wellfield-Model-Sec5to-8-Figures-Final.ashx

City of Olympia, Public Works Department, 2008, Report on wellhead protection area delineation for the City of Olympia Wellfield Areas, Thurston County, Washington: Olympia, Wash., Prepared by Golder Associates, Inc., 54 p. accessed November 5, 2013, at http://olympiawa.gov/documents/PublicWorks/GroundwaterProtection/WellheadProtectionAreaDelin eationsMay2008.pdf.

City of Olympia, Public Works Department, 2009, Water system plan for 2009-2014: Olympia, Wash., City of Olympia, Prepared under the direction of Tim Richardson, P.E., City of Olympia, and Jeff Hanson, P.E., HDR Engineering, Inc., accessed November 5, 2013, at http://olympiawa.gov/cityutilities/drinking-water/water-system-plan-for-2004-2014/water-system-plan-2009-2014-pdf-version.

City of Olympia, Public Works Department and Nisqually Indian Tribe, 2010, McAllister Wellfield Mitigation Plan. Olympia, Wash., accessed November 5, 2013, at http://olympiawa.gov/cityutilities/drinking-water/ /media/Files/PublicWorks/WaterResources/McAllister\%20Mitigation\%20Plan\%2012-2-10\%20with\%20cover.pdf. Appendix C technical memorandum-McAllister Wellfield Hydrologic Impacts Analysis: Olympia, Wash., Riley, M.J., (S.S. Papadopulos \& Associates, Inc.), to Rich Hoey and Donna Freier of City of Olympia. August 18, 2008, accessed November 5, 2013, at http://olympiawa.gov/city-utilities/drinkingwater/ /media/Files/PublicWorks/Water-Resources/MitigationPlan_Apx_C.pdf.

City of Yelm, 2011, City of Yelm water right mitigation plan: Yelm, Wash, City of Yelm, accessed November 5, 2013, at http://www.ci.yelm.wa.us/administrator/water/mitplan.htm.

Drost, B.W., Ely, D.M., and Lum II, W.E., 1999, Conceptual model and numerical simulation of the ground-water-flow system in the unconsolidated sediments of Thurston County, Washington. U.S. Geological Survey Water-Resources Investigations Report 99-4165, 254 p. 
Environmental Simulations, Inc., 2011, Command reference for Groundwater Vistas, version 6, Reinholds, PA, 379 p., software available via http://www.groundwatermodels.com/.

Environmental Systems Research Institute, Inc., 2010, ESRI ${ }^{\circledR}$ ArcMap $^{\mathrm{TM}}$ 10.0: Software available via http://www.esri.com/software/arcgis/arcgis-for-desktop.

HydroGeoLogic, Inc., 1996, MODHMS / MODFLOW-SURFACT Software Documentation :

HydroGeoLogic, Inc. Reston, VA. 860 p. Software (version 4.0) available via http://www.hglsoftware.com/ResourcesLibrary/Modflow-Surfact.pdf.

Johnson, K.H., Savoca, M.E., and Clothier, Burt, 2011, Numerical simulation of the groundwater-flow system in Chambers-Clover Creek watershed and vicinity, Pierce County, Washington: U.S.

Geological Survey Scientific Investigations Report 2011-5086, 55 p.

National Oceanic and Atmospheric Administration, 2012, National Climatic Data Center climate normals-1981-2010 normals data access for annual/seasonal normals for Olympia Airport, WA: National Oceanic and Atmospheric Administration database, accessed June 24, 2013, at http://www.ncdc.noaa.gov/data-access/land-based-station-data/land-based-datasets/climatenormals/1981-2010-normals-data.

Niswonger, R.G., Panday, Sorab, and Ibaraki, Motomu, 2011, MODFLOW-NWT, A Newton formulation for MODFLOW-2005: U.S. Geological Survey Techniques and Methods 6-A37, 44 p.

National Resources Conservation Service / PRISM Climate Group, 2013, PRISM climate mapping project-Parameter-elevation regressions on independent slopes model: PRISM Climate Group database, accessed April 26, 2013, at http://www.prism.oregonstate.edu/normals.

Pollock, D.W., 2012, User guide for MODPATH version 6-A particle-tracking model for MODFLOW: U.S. Geological Survey Techniques and Methods, book 6, chap. A41, 58 p.

Thurston County GeoData Center, 2013, County parcel database for 2012: Thurston County, Washington geodata database, accessed (by Washington State Dept. of Natural Resources) May 1, 2013, at http://www.geodata.org/.

U.S. Weather Bureau, 1965, State of Washington, mean annual precipitation, 1930-1957: Portland, Oregon, Soil Conservation Service, map M-4430, 1 sheet, [no scale].

Washington State Department of Ecology, 2013, Western Washington land cover change analysis project: 2006_Canopy and 2006_Landcover datasets, accessed April 5, 2013, at http://www.ecy.wa.gov/services/gis/data/landcover/landcover.htm

Washington State Department of Natural Resources, Geology and Earth Resources Division, 2010, Surface Geology: Olympia,Wash., Washington State Department of Natural Resources, 1:100,000 Scale, accessed October 25, 2013, at http://www.dnr.wa.gov/ResearchScience/Topics/GeosciencesData/Pages/gis_data.aspx.

Watermark Numerical Computing, 2010, PEST_model-independent parameter estimation, user manual (5th ed.): Watermark Numerical Computing, 336 p., accessed October 25, 2013, at http://www.pesthomepage.org/. 


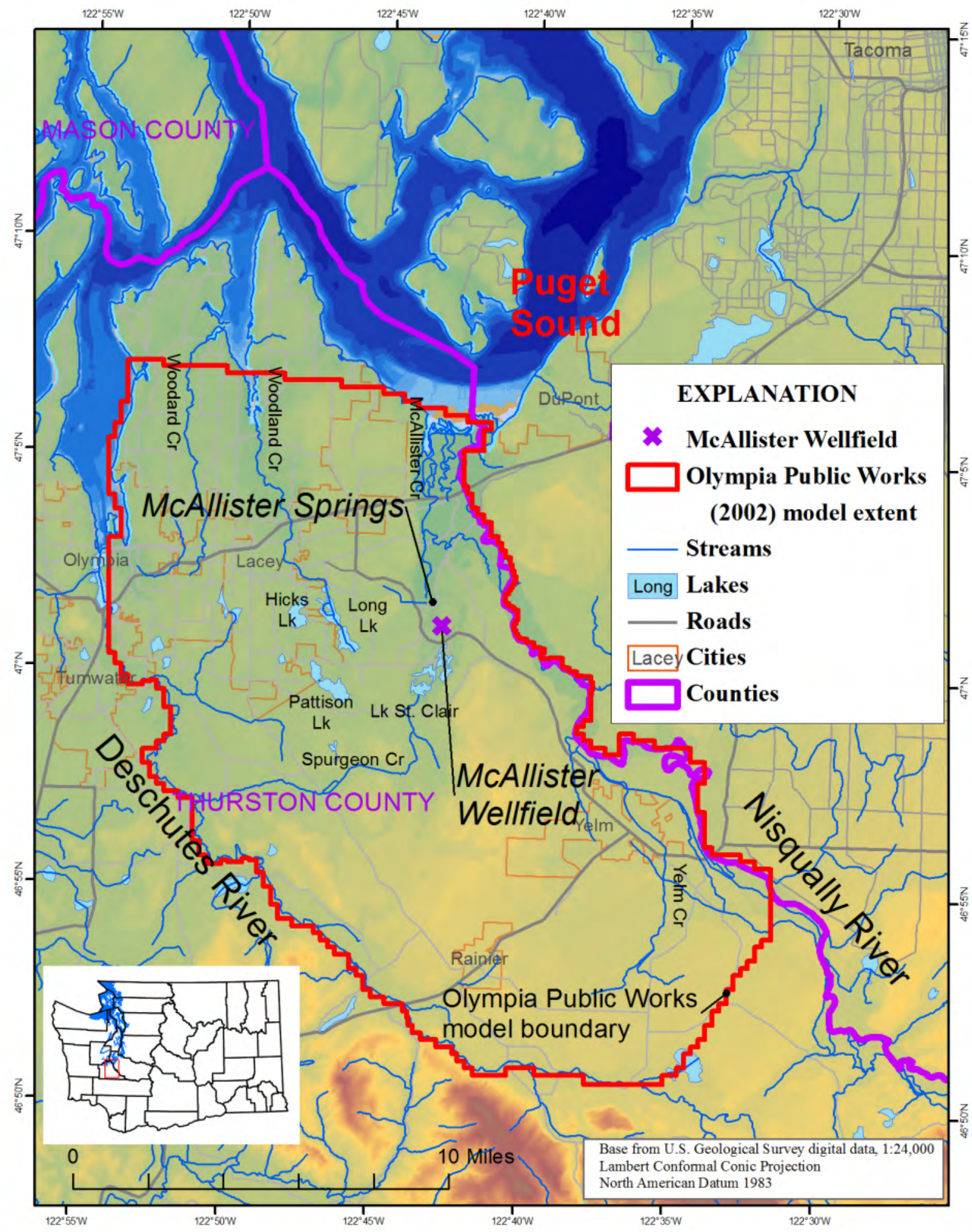

Figure 1. Map showing general vicinity of Olympia Public Works (2002) model extent and location of new McAllister Wellfield, Thurston County, Washington. 


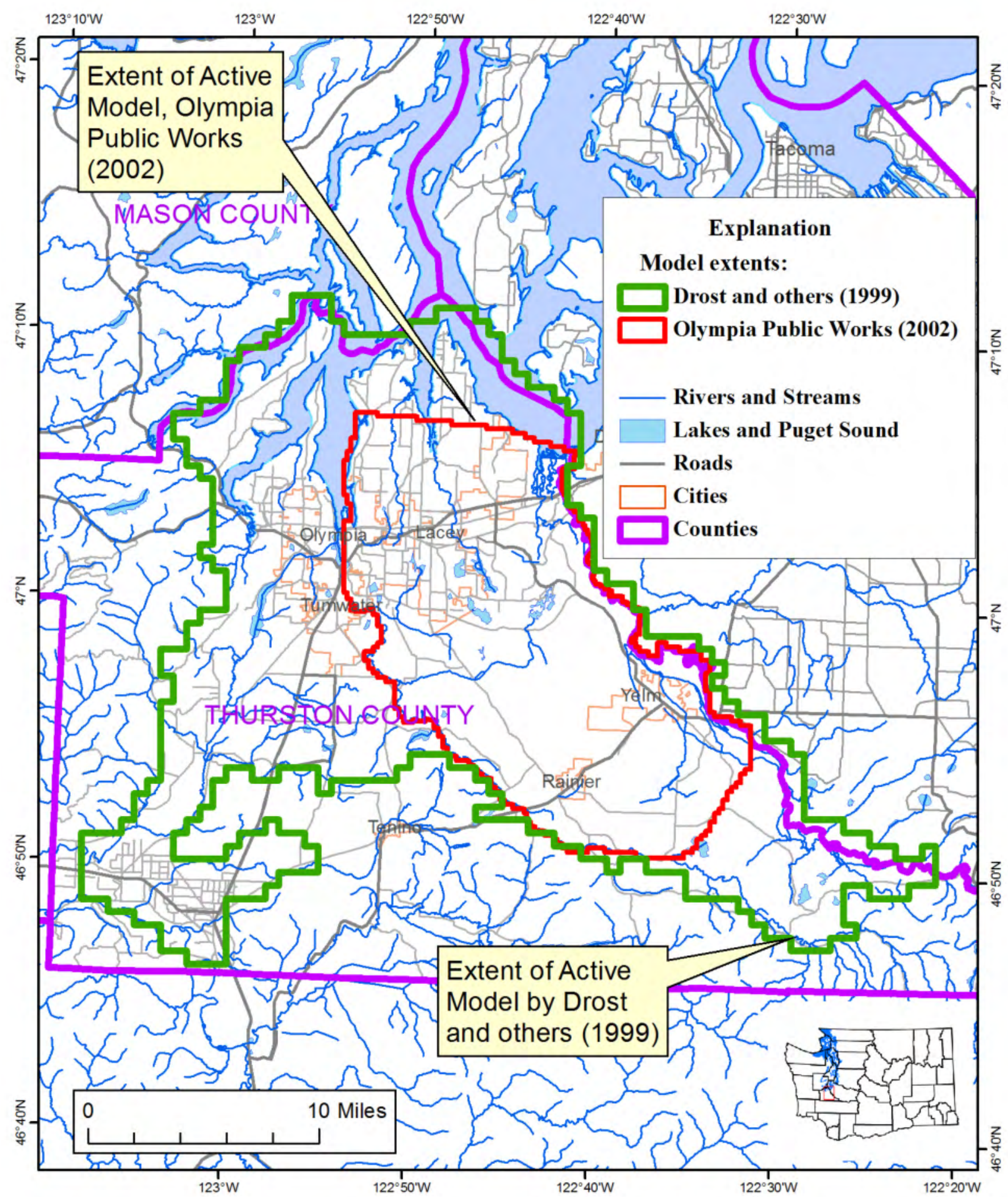

Figure 2. Map showing extent of active model by Drost and others (1999), compared to model developed for Olympia Public Works (2002), Thurston County, Washington. 


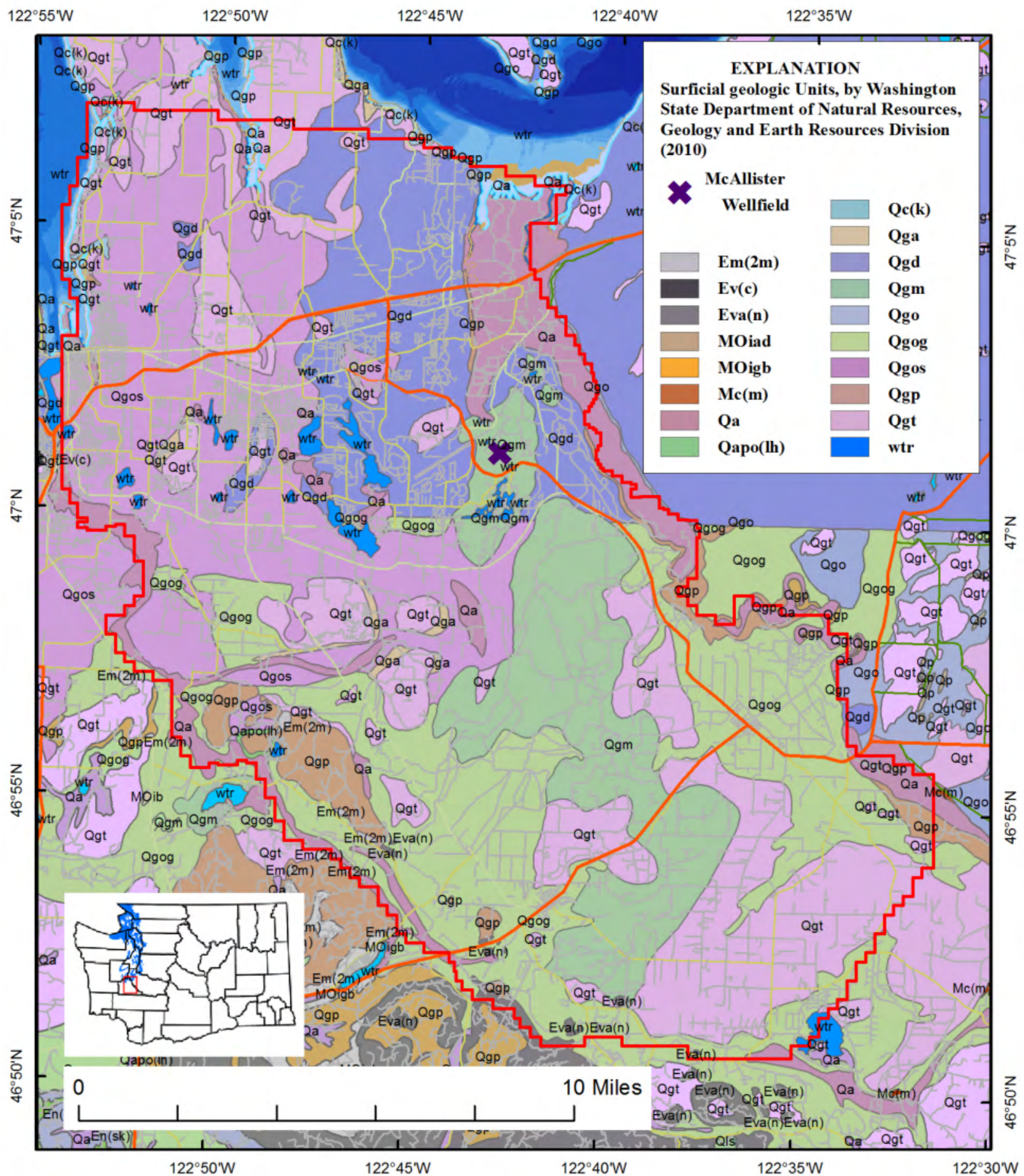

Figure 3. Map showing surficial geologic units (Washington State Department of Natural Resources, Geology and Earth Resources Division 2010), Thurston County, Washington. See table 3 for unit descriptions. 


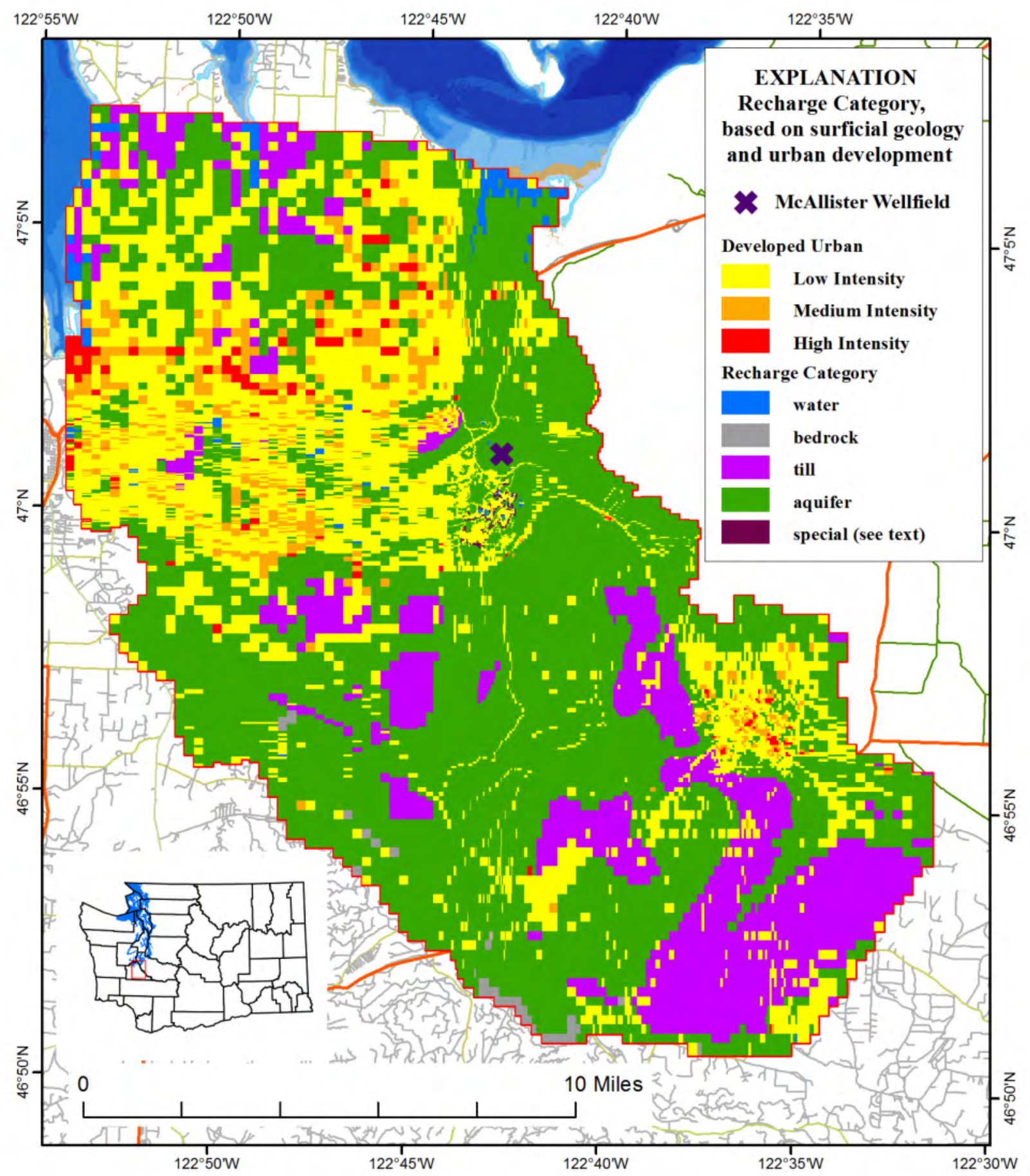

Figure 4. Map showing recharge category and developed land cover, Thurston County, Washington. 


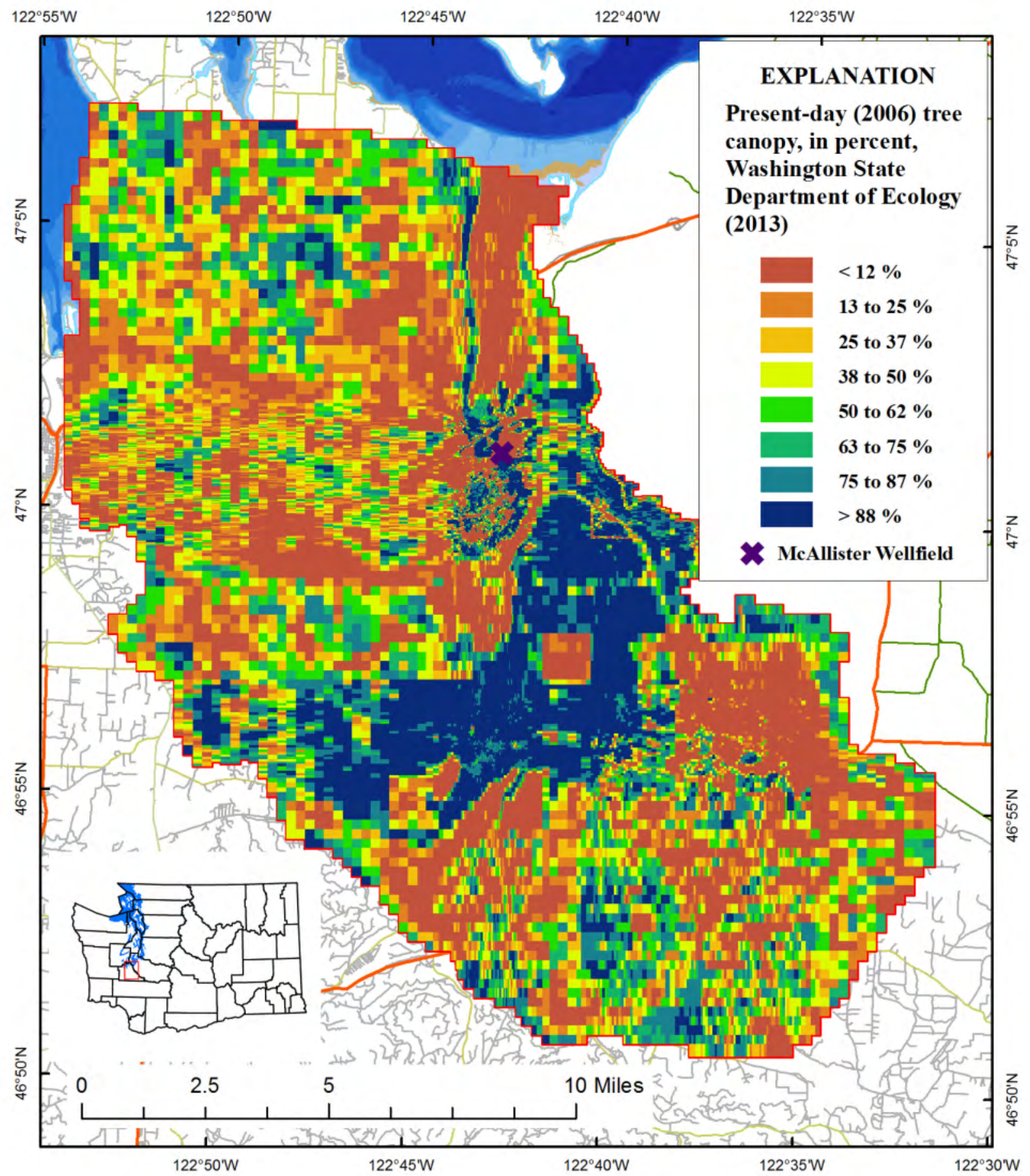

Figure 5. Map showing present-day (2006) Base Case (Scenario 1) tree canopy percentages, Thurston County, Washington. 


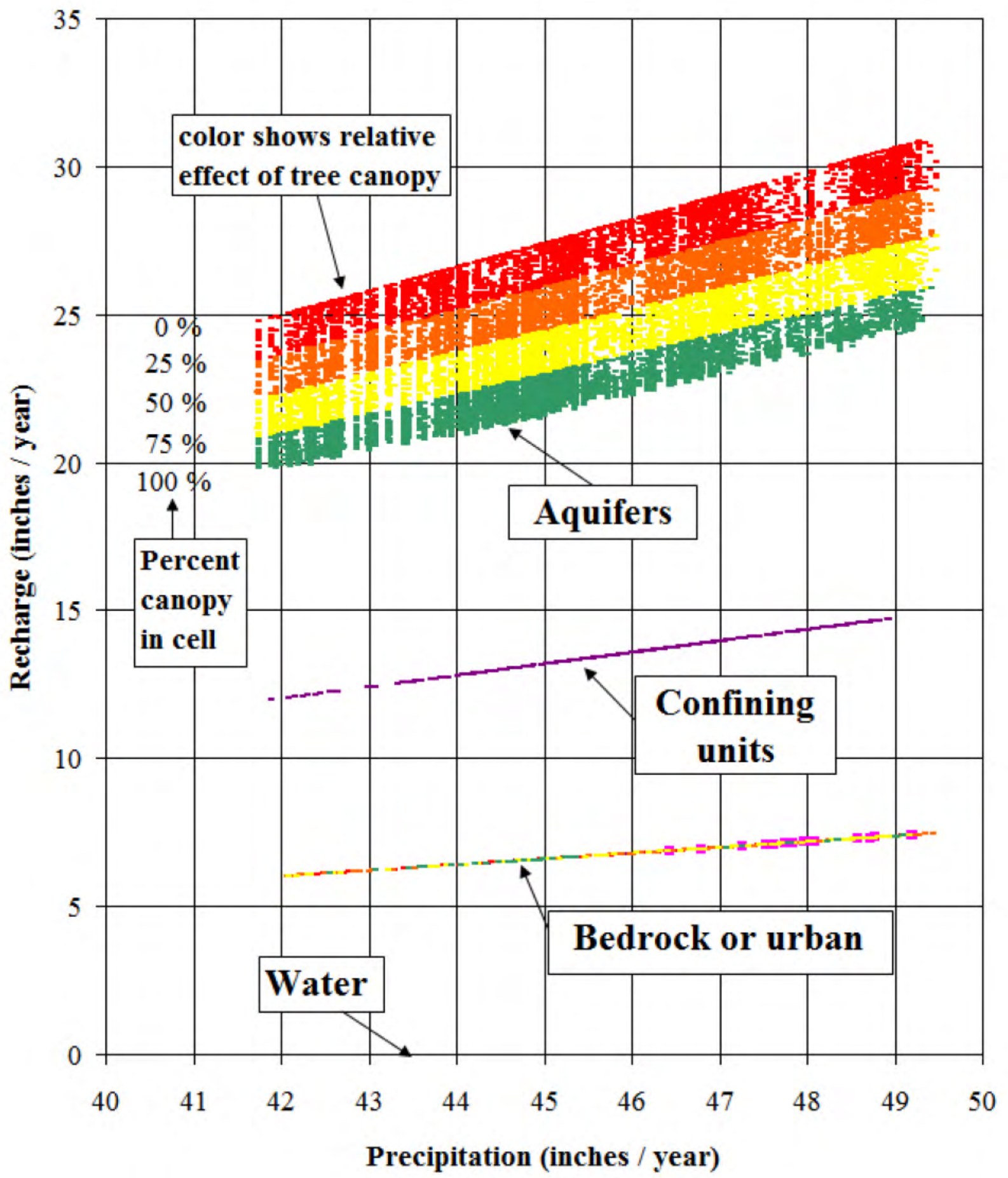

Figure 6. Graph showing precipitation / recharge relations used in this study (after Bidlake and Payne, 2001) for different recharge categories and varying canopy percentages on aquifer materials. 


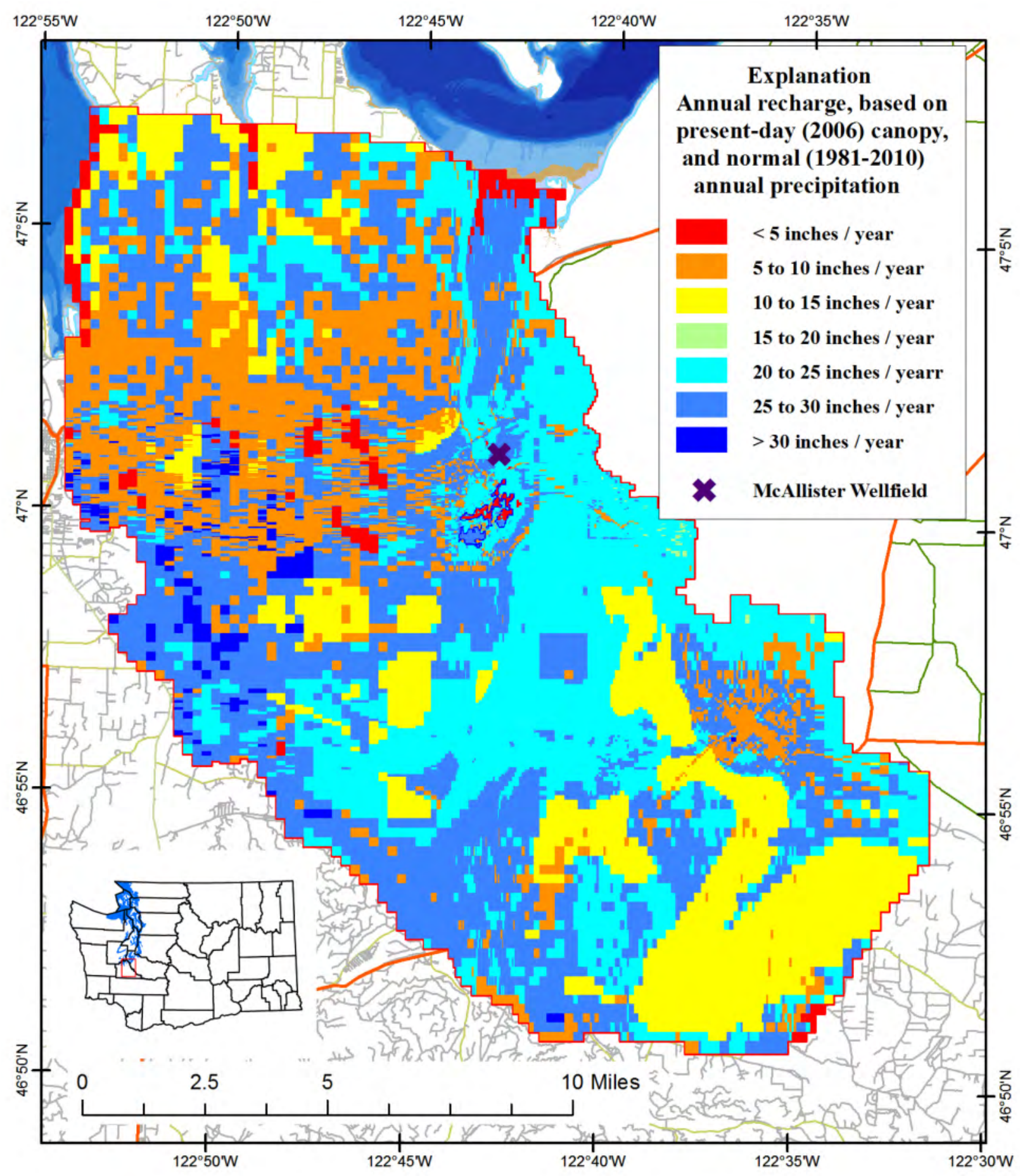

Figure 7. Map showing distribution of average annual groundwater recharge from normal precipitation for presentday (2006) Base Case (Scenario 1) tree canopy cover conditions, Thurston County, Washington. 


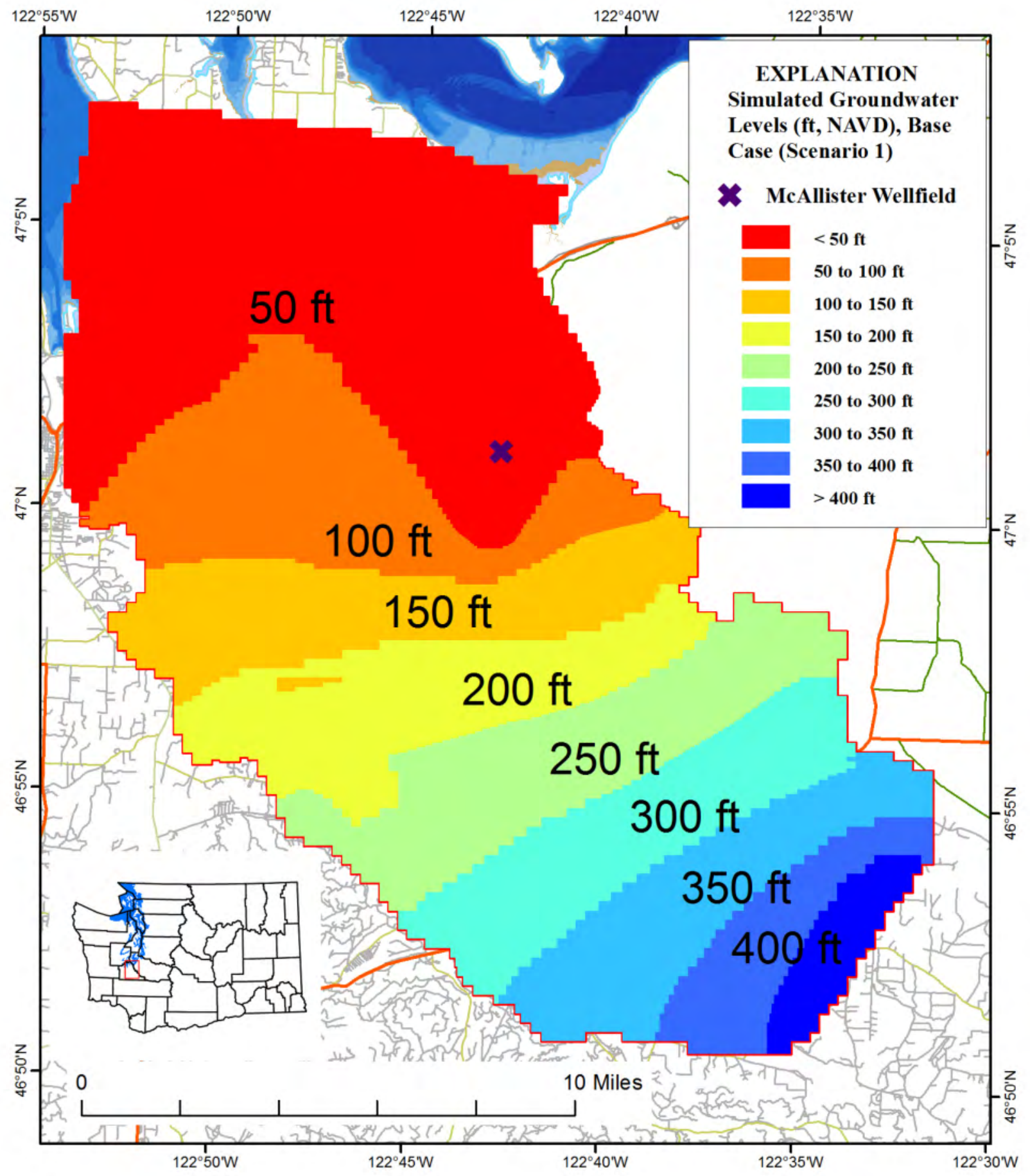

Figure 8. Map showing simulated groundwater levels averaged for model layers 7 and 8, for present-day (2006) Base Case (Scenario 1) recharge. NAVD 88, North American Vertical Datum of 1988; ft, feet. 


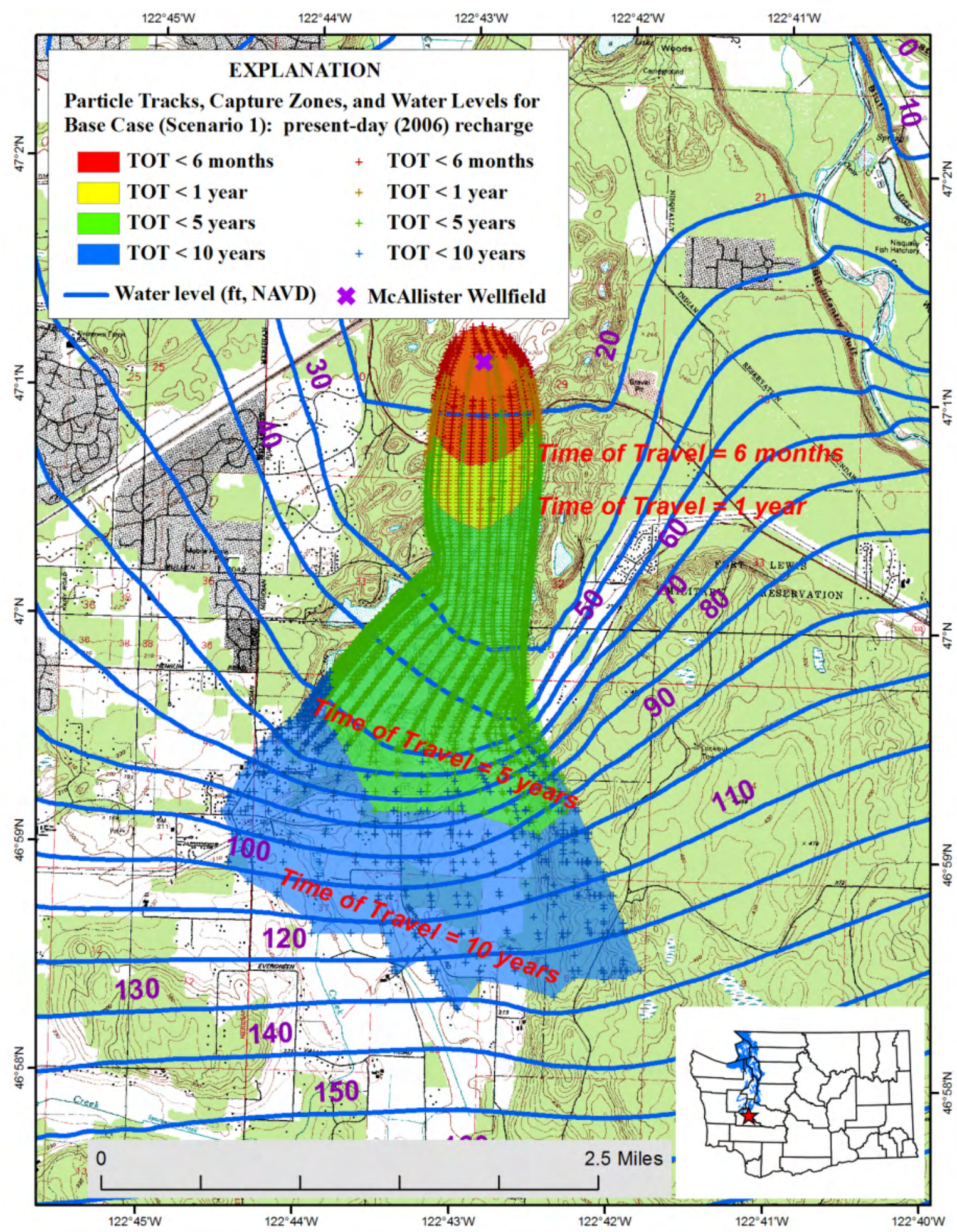

Figure 9. Map showing local simulated water levels, particle tracking, and capture zones for present-day (2006) recharge, Base Case (Scenario 1), Thurston County, Washington. NAVD 88, North American Vertical Datum of 1988; ft, feet. 


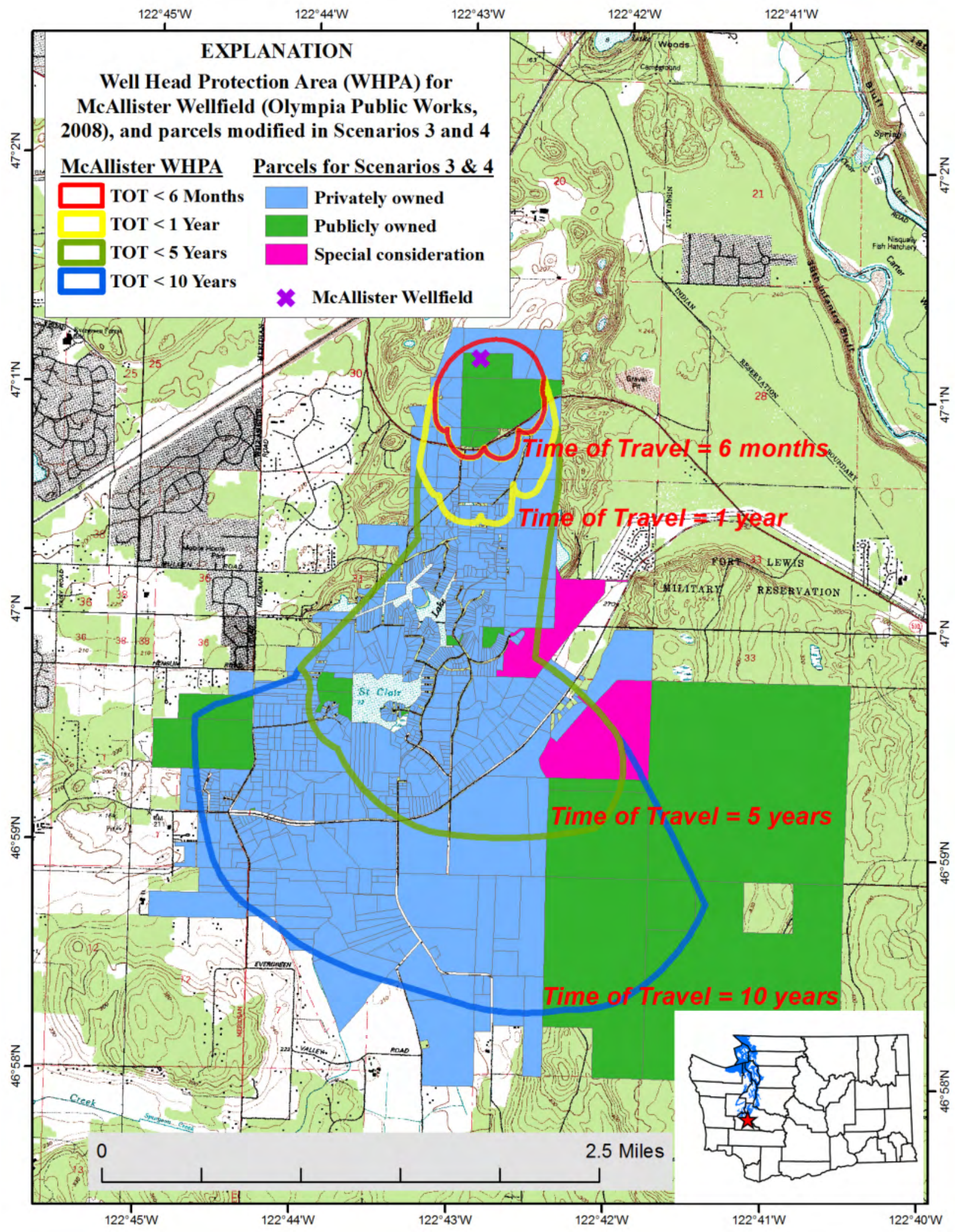

Figure 10. Previously mapped Wellhead Protection Area (Olympia Public Works, 2008) and parcels for modification in Scenarios 3 and 4. 


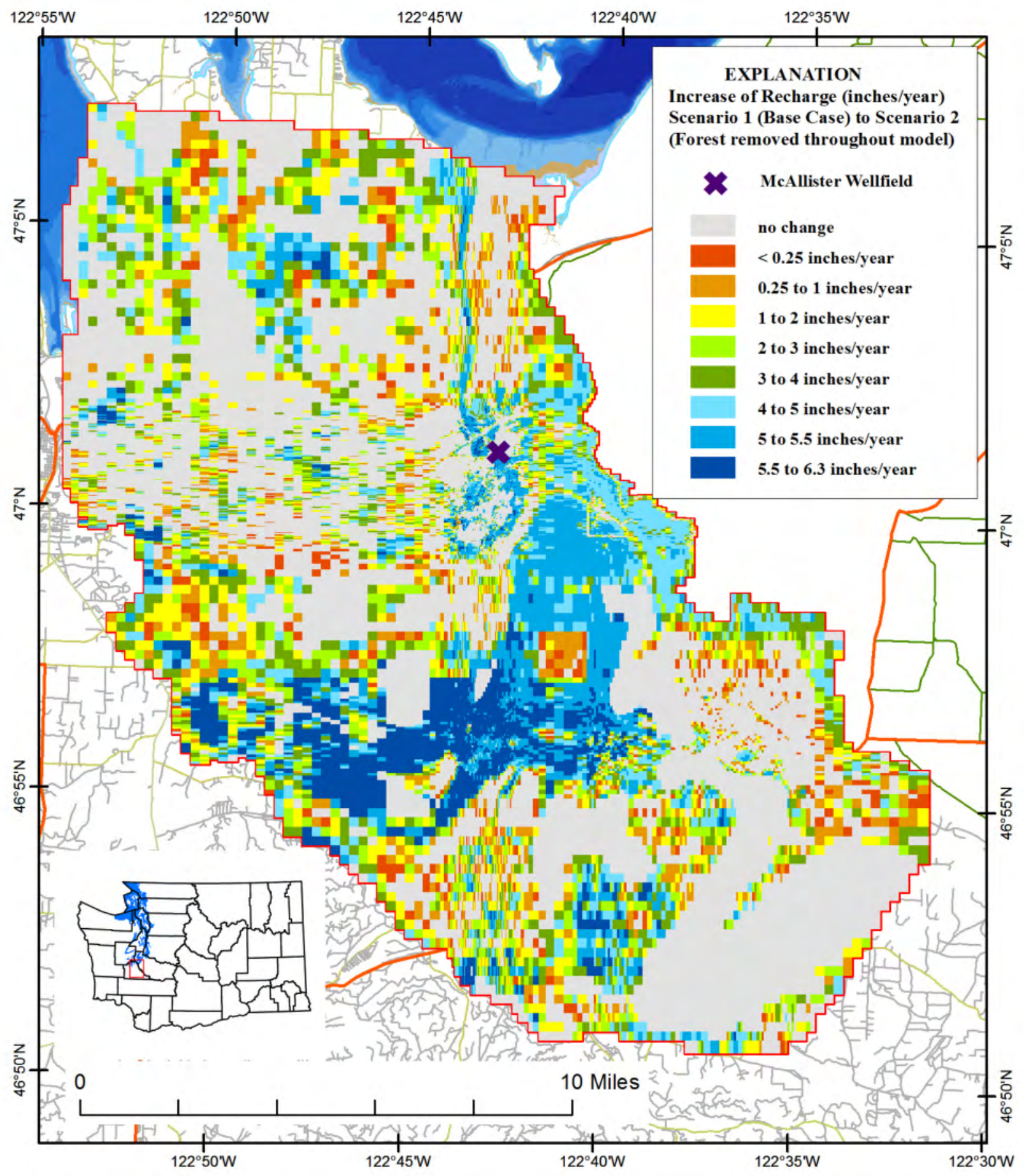

Figure 11. Map showing simulated change in recharge between Base Case (Scenario 1) and Scenario 2 (All Tree Canopy Removed), Thurston County, Washington. 


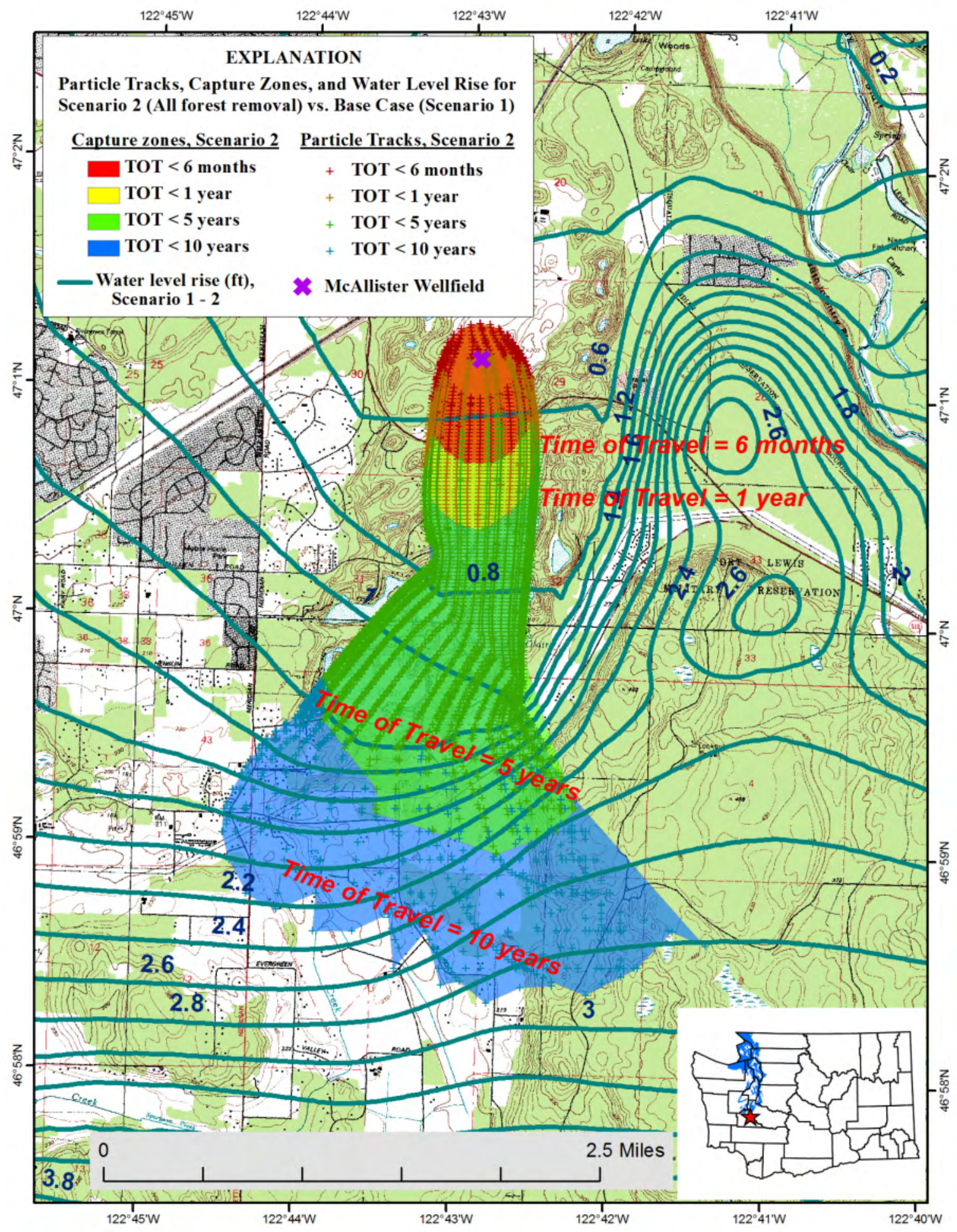

Figure 12. Map showing simulated groundwater-level change (ft) between the Base Case (Scenario 1) and Scenario 2 (all Tree Canopy removed throughout model area), averaged for model layers 7 and 8 , and particle tracks and capture zones for Scenario 2, Thurston County, Washington. 


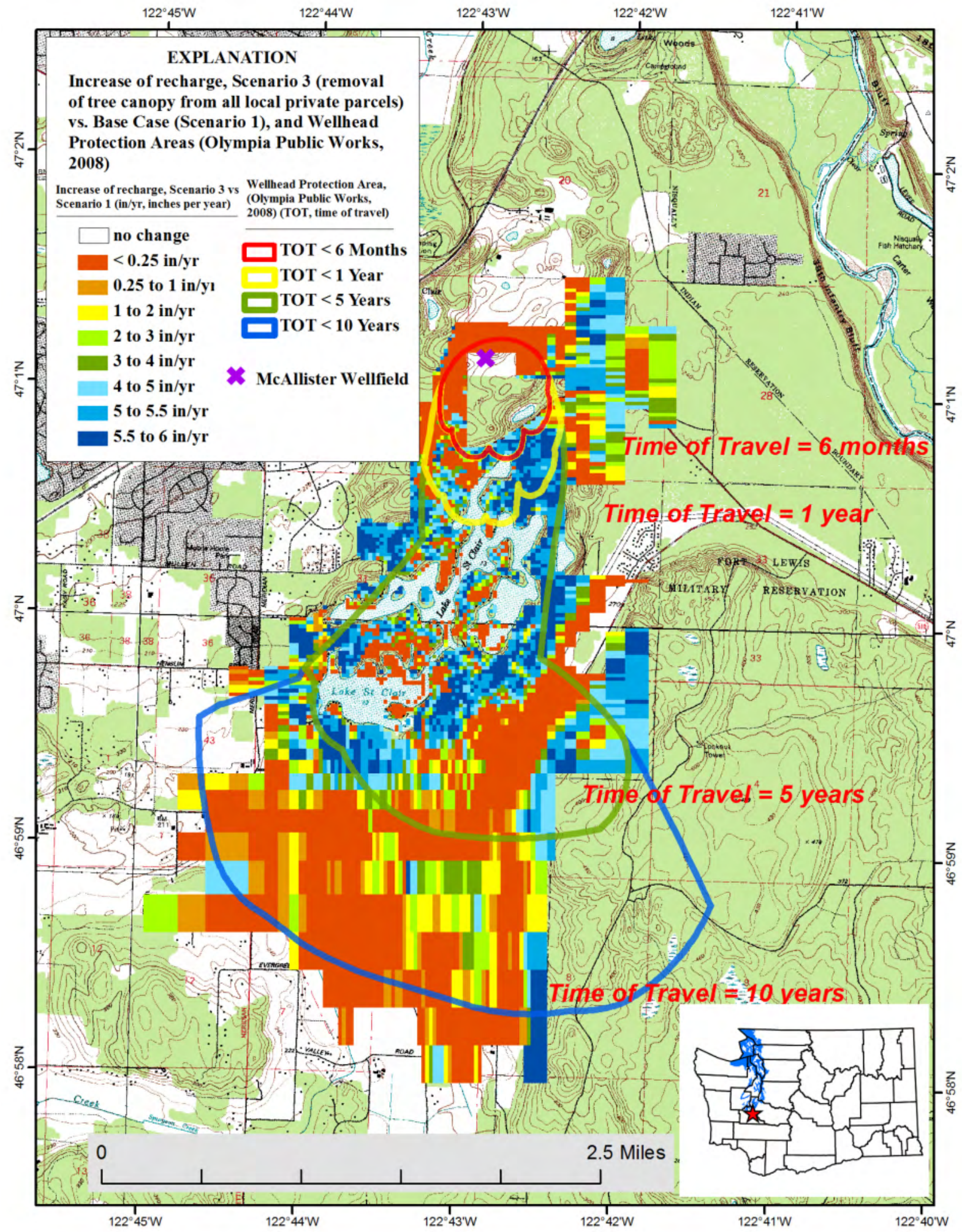

Figure 13. Map showing change of recharge for Scenario 3 (tree canopy removed from all local private parcels) compared to Base Case (Scenario 1) and previously mapped Wellhead Protection Areas (Olympia Public Works, 2008), Thurston County, Washington. 


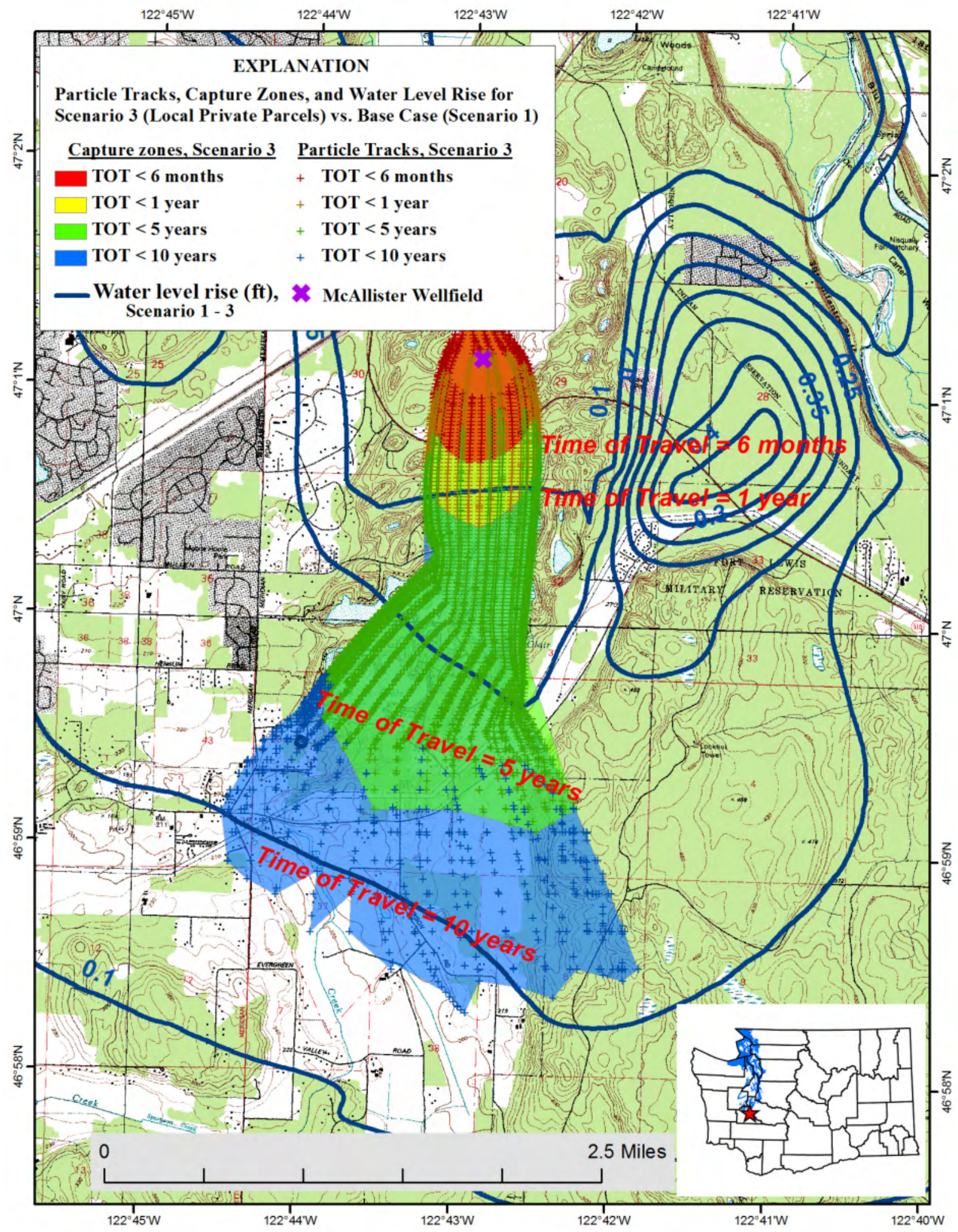

Figure 14. Change of simulated groundwater-level rise (in feet) compared to Base Case (Scenario 1), and particle tracks and capture zones for Scenario 3 (tree canopy removed from all local private parcels), Thurston County, Washington. 


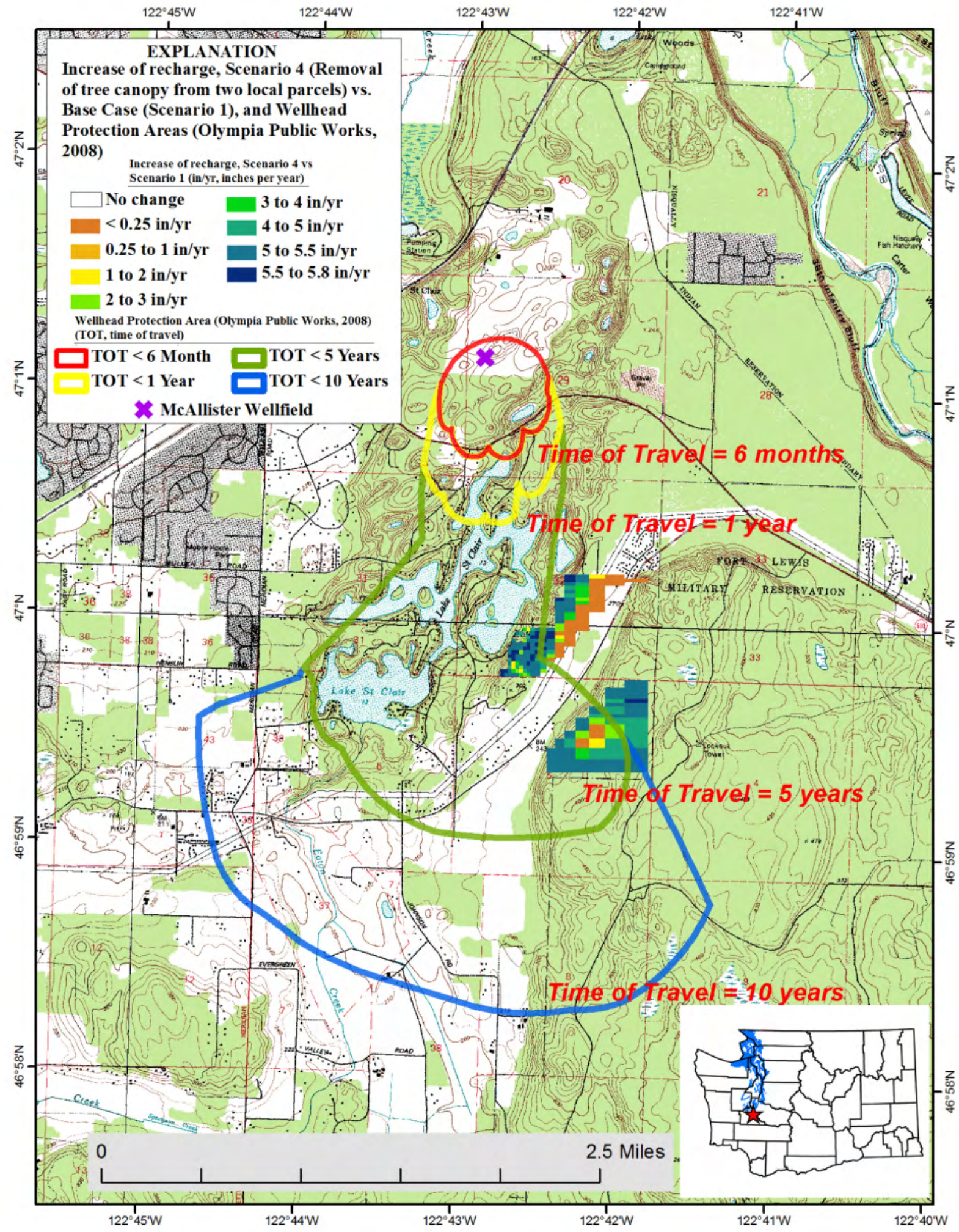

Figure 15. Map showing change of recharge for Scenario 4 (tree canopy removed from two parcels) compared to Base Case (Scenario 1) and previously mapped Wellhead Protection Areas (Olympia Public Works, 2008). 


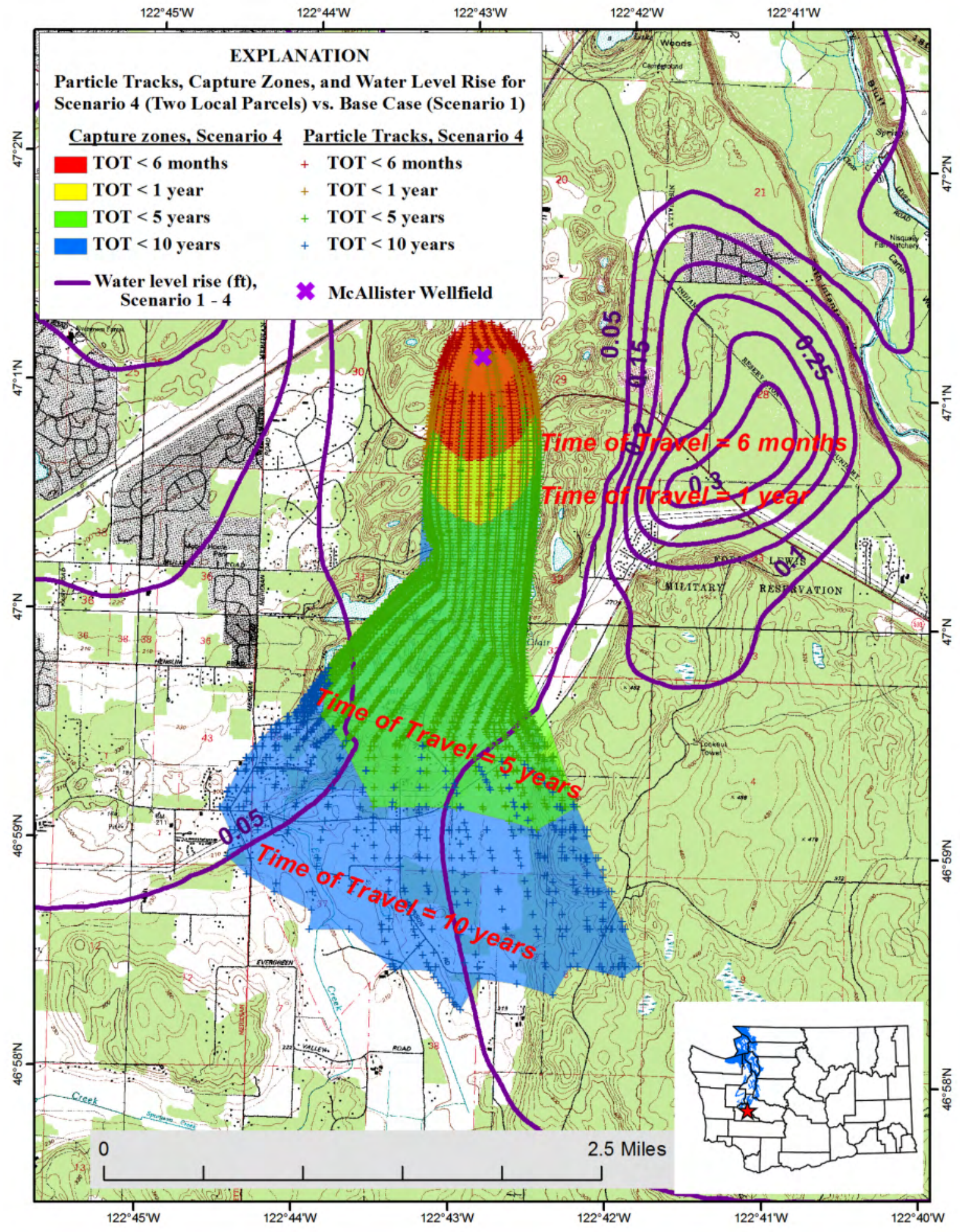

Figure 16. Map showing change in simulated groundwater level rise (ft), averaged for model layers 7 and 8 , for Scenario 4 compared to Base Case (Scenario 1), and particle tracks and capture zones for Scenario 4 (Tree canopy removed from two parcels), Thurston County, Washington. 
Table 1. Precipitation and recharge relationships used in this study.

[Source: Bidlake and Payne (2001, fig. 10). Regression equation: P, precipitation, in inches per year; R, recharge, in inches per year]

\begin{tabular}{llll}
\hline \multicolumn{1}{c}{ Surficial geology } & \multicolumn{1}{c}{ Vegetation } & \multicolumn{1}{c}{ Name } & Regression equation \\
\hline $\begin{array}{l}\text { Glacial outwash and other } \\
\text { alluvium } \\
\text { < same as above }>\end{array}$ & Nonforest & Nonforest, aquifer & $\mathrm{R}=0.806 \times \mathrm{P}-8.87$ \\
$\begin{array}{l}\text { Glacial till or fine-grained } \\
\text { sediments (confining unit) } \\
\text { Developed or urban land }\end{array}$ & Forest & Forest, aquifer & $\mathrm{R}=0.633 \times \mathrm{P}-6.96$ \\
\multicolumn{2}{c}{ Nonforest and forest } & Confining unit & $\mathrm{R}=0.388 \times \mathrm{P}-4.27$ \\
\hline
\end{tabular}


Table 2. Descriptions of hydrogeologic units and assigned model layers.

[Sources: Drost and others (1999) and Olympia Public Works (2002). NA, not applicable]

\begin{tabular}{|c|c|c|c|c|c|}
\hline $\begin{array}{l}\text { Hydro- } \\
\text { geologic } \\
\text { model }\end{array}$ & $\begin{array}{l}\text { Layer in } \\
\text { model of } \\
\text { Drost and } \\
\text { others } \\
(1999)\end{array}$ & $\begin{array}{l}\text { Layer in } \\
\text { model of } \\
\text { Olympia } \\
\text { Public } \\
\text { Works } \\
(\mathbf{2 0 0 2 )}\end{array}$ & $\begin{array}{l}\text { Recharge } \\
\text { category }\end{array}$ & Unit name & $\begin{array}{l}\text { Lithologic characteristics } \\
\text { from Drost and others (1999) } \\
\text { and Olympia Public Works (2002) }\end{array}$ \\
\hline Qvr & 1 & 1 & Aquifer & $\begin{array}{l}\text { Vashon } \\
\text { Recessional } \\
\text { Outwash }\end{array}$ & $\begin{array}{l}\text { Moderately to well-sorted glacial sand and gravel, } \\
\text { including kettled end moraine. } \\
\text { Principal surface unit. Mostly unconfined conditions. } \\
\text { Laterally discontinuous. }\end{array}$ \\
\hline Qvt & 2 & 2 & $\begin{array}{l}\text { Confining } \\
\text { Unit }\end{array}$ & $\begin{array}{l}\text { Vashon Glacial } \\
\text { Till }\end{array}$ & $\begin{array}{l}\text { Unsorted sand, gravel, and boulders in a matrix of } \\
\text { silt and clay. } \\
\text { Low permeable confining unit. Discontinuous } \\
\text { beneath Tri-lakes region. }\end{array}$ \\
\hline Qva & 3 & 3 & Aquifer & $\begin{array}{l}\text { Vashon Advance } \\
\text { Outwash }\end{array}$ & $\begin{array}{l}\text { Poorly to moderately well-sorted, well-rounded } \\
\text { gravel in a matrix of sand with some sand lenses. } \\
\text { Productive aquifer. Mostly confined. }\end{array}$ \\
\hline & & $2-8$ & Aquifer & $\begin{array}{l}\text { McAllister } \\
\text { Gravel }\end{array}$ & $\begin{array}{l}\text { Pebble- to boulder-sized sediments as a channel fill } \\
\text { deposit due to the ancestral Nisqually River channel. } \\
\text { Very high permeable unit cut through surrounding } \\
\text { units after the Kitsap Formation was deposited, } \\
\text { upgradient of McAllister Valley. }\end{array}$ \\
\hline Qf & 4 & 4 & $\begin{array}{l}\text { Confining } \\
\text { Unit }\end{array}$ & $\begin{array}{l}\text { Kitsap } \\
\text { Formation }\end{array}$ & $\begin{array}{l}\text { Predominantly clay and silt, with some layers of sand } \\
\text { and gravel. Minor amounts of peat and wood. } \\
\text { Low permeable confining unit. Layer } 4 \text { (in Olympia } \\
\text { Public Works [2002] model) also contains Recent } \\
\text { alluvial deposits in the McAllister Valley overlying } \\
\text { Qc. }\end{array}$ \\
\hline Qc & 5 & $5-6$ & Aquifer & $\begin{array}{l}\text { Salmon Springs } \\
\text { Formation (Sea } \\
\text { Level Aquifer) \& } \\
\text { Penultimate } \\
\text { Glaciation }\end{array}$ & $\begin{array}{l}\text { Coarse sand and gravel, deeply stained with red or } \\
\text { brown iron oxides. } \\
\text { Key productive aquifer. Total unit thickness equally } \\
\text { divided between two model layers (in Olympia } \\
\text { Public Works [2002] model). }\end{array}$ \\
\hline TQu & $6,7,8$ & $7-9$ & Aquifer & $\begin{array}{l}\text { Undifferentiated } \\
\text { Quaternary and } \\
\text { Tertiary }\end{array}$ & $\begin{array}{l}\text { Various layers of clay, silt, sand, and gravel of both } \\
\text { glacial and nonglacial origin. } \\
\text { Uppermost } 50 \mathrm{ft} \text { is low permeable confining unit. } \\
\text { Greatest thickness near Puget Sound, thins to south. } \\
\text { Glacial and non-glacial. }\end{array}$ \\
\hline $\mathrm{Tb}$ & NA & NA & Bedrock & Bedrock & $\begin{array}{l}\text { Sedimentary rocks consisting of claystone, siltstone, } \\
\text { sandstone, and minor beds of coal. Igneous bodies of } \\
\text { andesite and basalt. }\end{array}$ \\
\hline
\end{tabular}


Table 3. Scale 1:100,000 Geologic Units from Washington State Department of Natural Resources, Geology and Earth Resources Division (2010) and assigned recharge categories.

\begin{tabular}{|c|c|c|}
\hline $\begin{array}{c}\text { Geologic } \\
\text { unit }\end{array}$ & Description & Recharge category \\
\hline $\operatorname{Em}(2 m)$ & marine sedimentary rocks, McIntosh Formation & Bedrock \\
\hline $\operatorname{Ev}(\mathrm{c})$ & basalt flows and flow breccias, Crescent Formation & “ \\
\hline Eva(n) & andesite flows, Northcraft Formation & “ \\
\hline MOiad & intrusive andesite and dacite & “ \\
\hline MOigb & gabbro & “ \\
\hline $\operatorname{Mc}(\mathrm{m})$ & continental sedimentary deposits or rocks, Mashel Formation & \\
\hline Qa & alluvium & Aquifer \\
\hline Qapo(lh) & alpine glacial outwash, pre-Fraser, Logan Hill Formation & “ \\
\hline $\mathrm{Qc}(\mathrm{k})$ & continental sedimentary deposits or rocks, Kitsap Formation & Confining unit \\
\hline Qga & advance continental glacial outwash, Fraser-age, mostly Vashon Stade & Aquifer \\
\hline Qgd & continental glacial drift, Fraser-age, mostly Vashon Stade & "“ \\
\hline Qgm & continental glacial moraines, Fraser-age, mostly Vashon Stade & “ \\
\hline Qgo & continental glacial outwash, Fraser-age, mostly Vashon Stade & “ \\
\hline Qgog & continental glacial outwash, gravel, Fraser-age, mostly Vashon Stade & “ \\
\hline Qgos & continental glacial outwash, sand, Fraser-age mostly Vashon Stade & “ \\
\hline Qgp & continental glacial drift, pre-Fraser & “ \\
\hline Qgt & continental glacial till, Fraser-age mostly Vashon Stade & Confining unit \\
\hline wtr & surface water bodies & Water \\
\hline
\end{tabular}

Table 4. Tree canopy changes for recharge inputs in four scenarios.

\begin{tabular}{cl}
\hline Scenario number & \multicolumn{1}{c}{ Canopy } \\
\hline 1 & Base Case: Present-day (2006) tree canopy cover \\
2 & All tree canopy removed throughout model extent \\
3 & Tree canopy removed from all privately owned parcels in Wellhead Protection Area \\
4 & Tree canopy removed from only two parcels (36440004100 and 21832340000) \\
\hline
\end{tabular}


Table 5. Change of recharge for four scenarios, and effects.

[acre-ft/yr, acre feet per year]

\begin{tabular}{ccccccc}
\hline Scenario & $\begin{array}{c}\text { Recharge } \\
\text { (acre-ft/yr) }\end{array}$ & $\begin{array}{c}\text { Increase of } \\
\text { recharge from } \\
\text { Scenario 1 } \\
\text { (acre-ft/yr) }\end{array}$ & $\begin{array}{c}\text { Fraction of } \\
\text { Scenario 1 } \\
\text { recharge } \\
\text { (percent) }\end{array}$ & $\begin{array}{c}\text { Constant head } \\
\text { (acre-ft/yr) }\end{array}$ & $\begin{array}{c}\text { Drain } \\
\text { (acre-ft/yr) }\end{array}$ & $\begin{array}{c}\text { River } \\
\text { (acre-ft yr) }\end{array}$ \\
\hline 1 & 213,271 & & & & 5,955 & 6,260 \\
2 & 233,656 & 20,384 & 9.56 & 8,169 & 339 \\
3 & 213,825 & 553 & 0.26 & 131 & 63 & 11 \\
4 & 213,333 & 61 & 0.03 & -13 & 63 & \\
\hline
\end{tabular}

Table 6. Change in area of Capture Zone for four scenarios.

[TOT, time of travel]

\begin{tabular}{|c|c|c|c|c|}
\hline \multirow[b]{2}{*}{ Source of Capture Zone delineation } & \multicolumn{4}{|c|}{ Area of Capture Zone (acres) } \\
\hline & 6-month TOT & 1-year TOT & 5-year TOT & 10-year TOT \\
\hline $\begin{array}{c}\text { Previously-mapped Wellhead } \\
\text { Protection Area (Olympia Public } \\
\text { Works 2008) }\end{array}$ & 165 & 307 & 1,474 & 2,961 \\
\hline Present study: Scenario & & & & \\
\hline 1 & 180 & 293 & 1,122 & 2,145 \\
\hline 2 & 182 & 298 & 1,190 & 2,219 \\
\hline 3 & 180 & 293 & 1,145 & 2,140 \\
\hline 4 & 180 & 293 & 1,146 & 2,113 \\
\hline
\end{tabular}


This page left intentionally blank 
Publishing support provided by the U.S. Geological Survey

Publishing Network, Tacoma Publishing Service Center

For more information concerning the research in this report, contact the

Director, Washington Water Science Center

U.S. Geological Survey

934 Broadway, Suite 300

Tacoma, Washington 98402

http://wa.water.usgs.gov 


\section{$\frac{\mathbb{1}}{50}$}

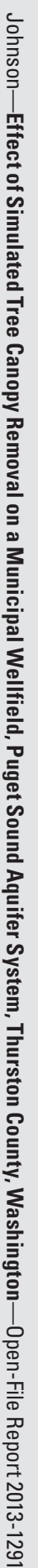

